\title{
Archaeological Testing and Monitoring of a Service Drive at Mission San Juan Capistrano, San Antonio, Texas
}

Diane A. Cargill

Center for Archaeological Research

Rick C. Robinson

Center for Archaeological Research

Follow this and additional works at: https://scholarworks.sfasu.edu/ita

Part of the American Material Culture Commons, Archaeological Anthropology Commons, Environmental Studies Commons, Other American Studies Commons, Other Arts and Humanities Commons, Other History of Art, Architecture, and Archaeology Commons, and the United States History Commons

Tell us how this article helped you.

This Article is brought to you for free and open access by the Center for Regional Heritage Research at SFA ScholarWorks. It has been accepted for inclusion in Index of Texas Archaeology: Open Access Gray Literature from the Lone Star State by an authorized editor of SFA ScholarWorks. For more information, please contact cdsscholarworks@sfasu.edu. 


\section{Archaeological Testing and Monitoring of a Service Drive at Mission San Juan Capistrano, San Antonio, Texas}

\section{Creative Commons License}

\section{(c) (1) (8)}

This work is licensed under a Creative Commons Attribution-NonCommercial 4.0 International License 


\section{Archaeological Testing and Monitoring of a Service Drive at}

Mission San Juan Capistrano, San Antonio, Texas

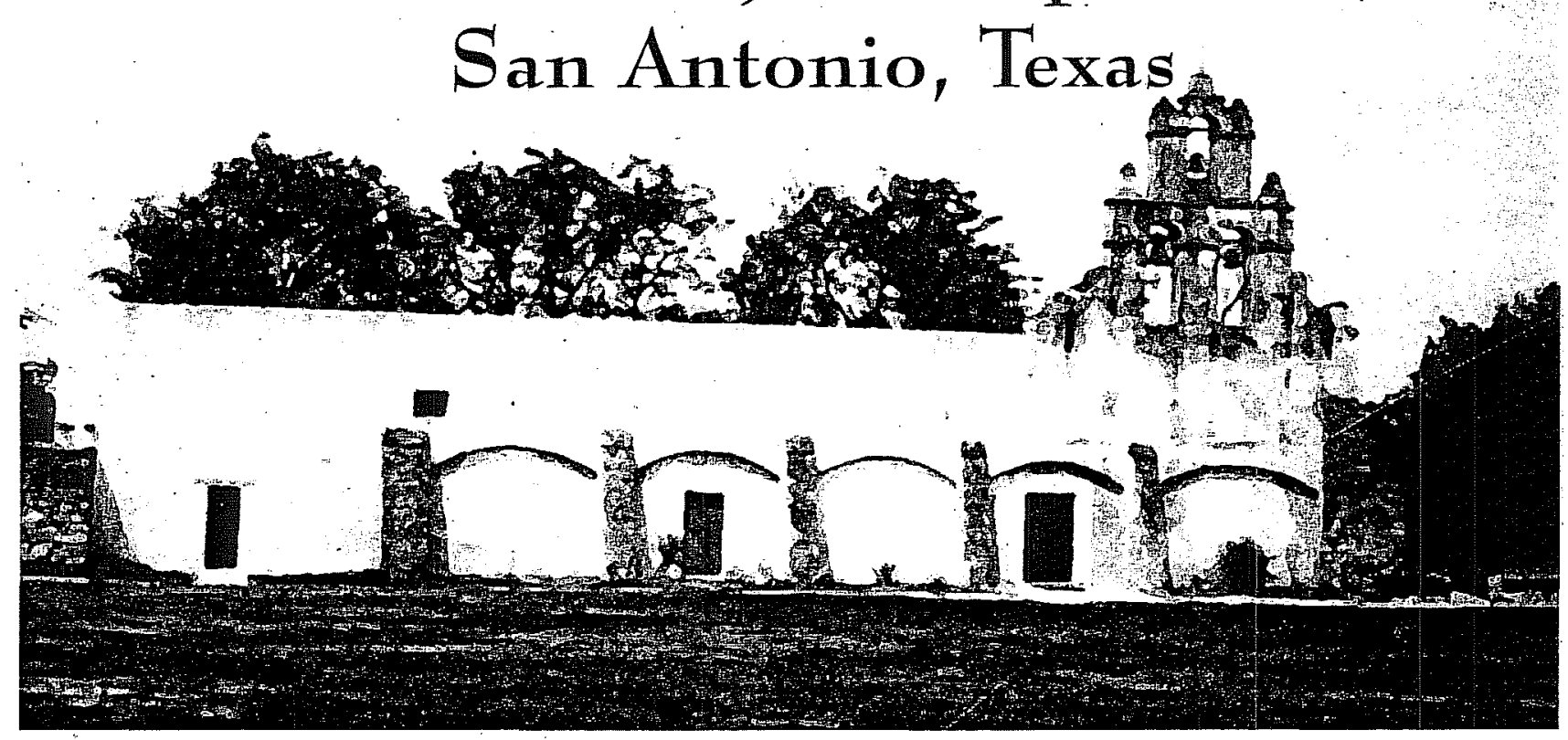

Diane A. Cargill and Rick C. Robinson

with a Contribution by Barbara A. Meissner

and Appendices by

Jeffrey R. Francis and Thomas R. Hester

Center for Archaeological Research The University of Texas at San Antonio Archaeological Survey Report, No. 296 2000

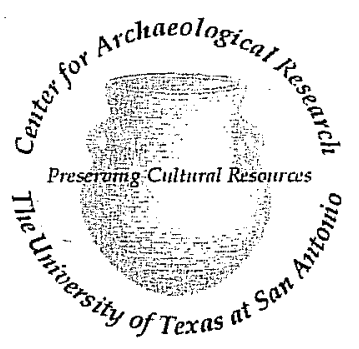





\title{
Archaeological Testing and Monitoring of a Service Drive at Mission San Juan Capistrano, San Antonio, Texas
}

\author{
Diane A. Cargill and Rick C. Robinson \\ with a Contribution by \\ Barbara A. Meissner \\ and Appendices by \\ Jeffrey R. Francis and Thomas R. Hester
}

\section{Robert J. Hard and C. Britt Bousman Principal Investigators}

Texas Antiquities Permit No. 1908

${ }^{\circ}$ copyright 2000

Center for Archaeological Research

The University of Texas at San Antonio

Archaeological Survey Report, No. 296 
The following information is provided in accordance with the General Rules of Practice and Procedure, Chapter 41.11 (Investigative Reports), Texas Antiquities Committee:

1. Type of investigation: Testing and monitoring

2. Project name: Mission San Juan Capistrano Service Drive

3. County: Bexar

4. Principal investigators: Robert J. Hard and C. Britt Bousman

5. Name and location of sponsoring agency: National Park Service, San Antonio Missions National Historical Park, San Antonio, Texas

6. Texas Antiquities Permit No.: 1908

7. Published by the Center for Archaeological Research, The University of Texas at San Antonio, 6900 N. Loop 1604 W., San Antonio, Texas 78249-0658, 2000

A list of publications offered by the Center for Archaeological Research is available. Call (210) 458-4378; or write to the Center for Archaeological Research, The University of Texas at San Antonio, 6900 N. Loop 1604 W., San Antonio, Texas 78249-0658; e-mail address is car@lonestar.utsa.edu; or visit CAR's web site at http://car.utsa.edu. 


\begin{abstract}
Archaeological testing for the installation of a new service drive and monitoring the removal of the existing service drive at Mission San Juan Capistrano was conducted in November, 1997 and October, 1999 respectively, by the Center for Archaeological Research (CAR) at The University of Texas at San Antonio (UTSA) for the National Park Service (NPS). The results of the testing and monitoring indicated that no intact Colonial midden deposits were observed, and few Colonial artifacts were recovered within the proposed service drive right-ofway. Three post-Colonial trash deposits were documented within the project area; however, due to the disturbed nature of these deposits which contain stratigraphically mixed nineteenth and twentieth century materials the research potential of such deposits is considered minimal and it is recommended that no further archaeological investigations are required prior to the construction of the service drive.
\end{abstract}

Also included as an Appendix to this report is a brief analysis of an isolated burial discovered during a monitoring project at Mission San Juan in 1999. These remains have since been reinterred by NPS. 


\section{Contents}

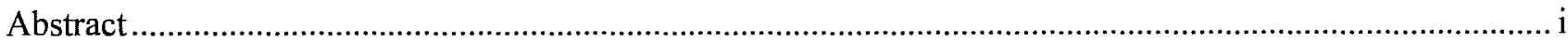

Figures

Tables

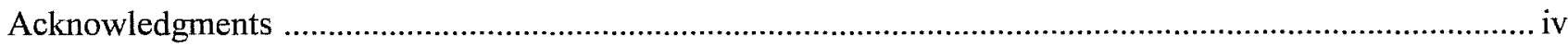

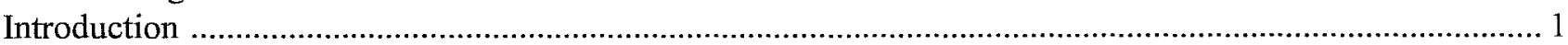

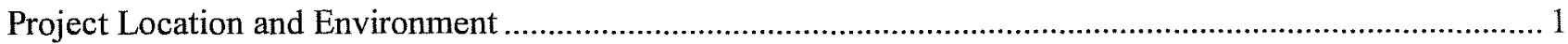

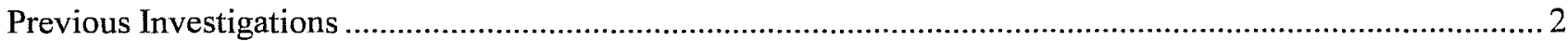

Methodology

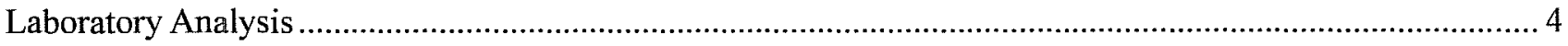

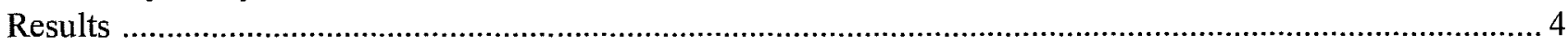

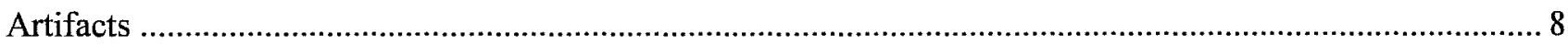

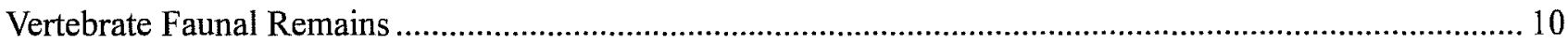

Archaeological Monitoring at Mission San Juan Capistrano ......................................................... 13

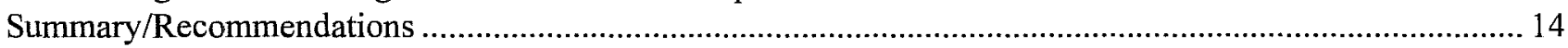

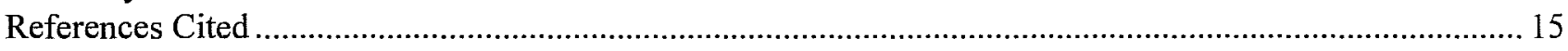

Appendix I

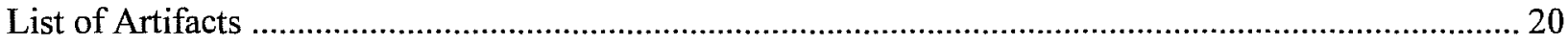

Appendix II

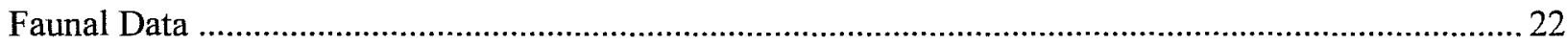

Appendix III

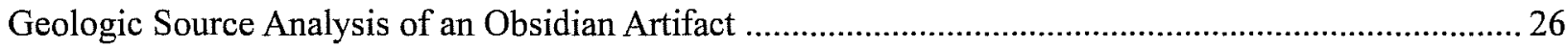

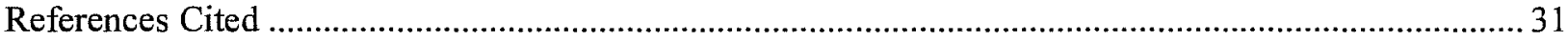

Appendix IV

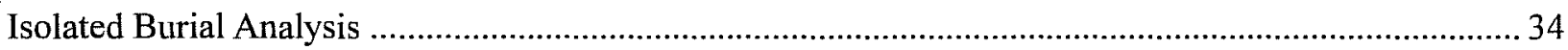




\section{Figures}

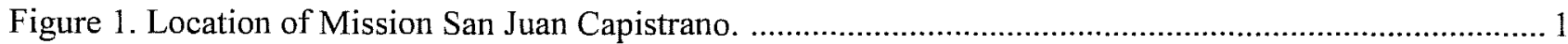

Figure 2. Area of investigation at Mission San Juan Capistrano. ........................................................ 3

Figure 3-1. Drawing of obsidian fragment obtained from Unit 2, Mission San Juan. ................................26

Figure 3-2. Map indicating location of Mission San Juan (41BX5), in relation to Ucareo source. ................26

Figure 4-1. Route of drainage channel and location of previously excavated shovel tests. ......................... 35

\section{Tables}

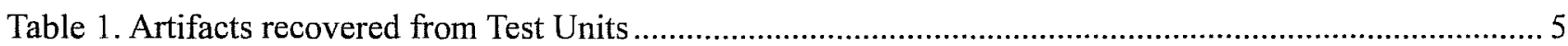

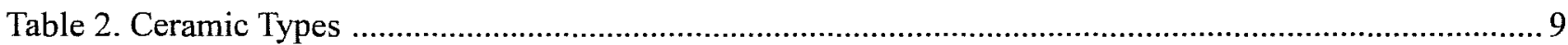

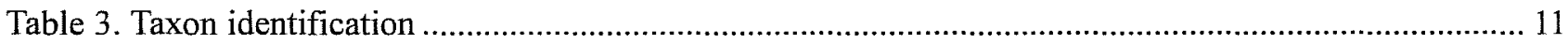

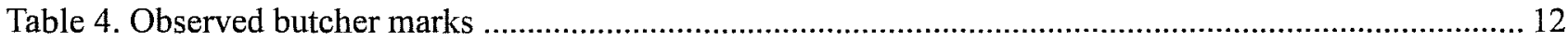

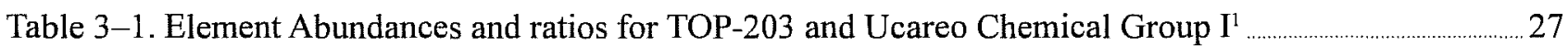

Table 3-2. Element abundances and ratios for TOP-203 and Ucareo Chemical Group $\mathrm{I}^{1}$..................................28

Table 3-3. Element abundances and ratios for TOP-203 and Ucareo Chemical Group III ${ }^{1} \ldots \ldots \ldots \ldots \ldots \ldots \ldots \ldots \ldots \ldots \ldots \ldots \ldots . . . \ldots \ldots$

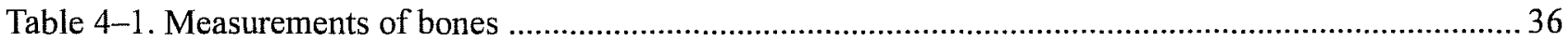




\section{Acknowledgments}

Several people have contributed in various ways to the completion of this project. Thanks goes to Mark Chavez of the National Park Service for his assistance during the planning and field stages of this project. Thanks to Nancy Kenmotsu of the Texas Department of Transportation, and Mark Denton of the Texas Historical Commission for their advice and tracking efforts in retrieving old field notes and profiles.

I would like to thank Robert J. Hard and C. Britt Bousman, for serving as co-principal investigators. Critical to any field investigation is a dedicated field crew; therefore, many thanks go to Donna Edmondson, Toni Figueroa, Kevin Hanselka, Kim Kvernes, Tony Lyle; aided by student intern Chris Cooley. Barbara Meissner of CAR analyzed the faunal remains and Bruce Moses drafted the maps and illustrated the artifacts in this report. I am most grateful to Anne Fox of CAR, for being such a valuable resource on Spanish Colonial missions in Texas. Thanks are also extended to our technical editor, Maryanne King. 


\section{Introduction}

Archaeological testing for the installation of a new service drive and monitoring the removal of the existing service drive at Mission San Juan Capistrano was conducted in November, 1997 and October, 1999, respectively, by the Center for Archaeological Research (CAR) of The University of Texas at San Antonio (UTSA) for the National Park Service (NPS).

Mission San Juan Capistrano (41BX5) is located on the left bank of the San Antonio River approximately seven miles south of downtown San Antonio (Figure 1). It is part of the San Antonio Missions National Historical Park and is listed on the National Register of Historic Places. In compliance with Section 106 of the National Historic Preservation Act of 1966 and the Texas Antiquities Code, the archaeological testing and monitoring was conducted under Texas Antiquities Permit No. 1908.

This investigation was necessitated by NPS plans to install a new service drive and remove the existing asphalt service driveway. The new service drive with a 20 foot right-of-way, will extend approximately 320 feet north from an existing parking area and connect with Padre Drive (Figure 2). This will replace the existing service drive which currently enters the mission from the north, turns to the west and runs parallel to the north wall of the compound.

Midden deposits have been documented east of the north wall gateway (Turner 1988) and near the western end of the north compound wall (Scurlock et al. 1976). Therefore, the current investigations were focused on the potential of encountering these midden deposits. Three 3-x-3-ft units, 14 shovel tests, and one backhoe trench were excavated along the route of the new service drive (Figure 2). The testing portion of the investigation was accomplished in fourteen person days while the monitoring portion, reported here separately, was completed in four days.

\section{Project Location and Environment}

Mission San Juan is located on the east side of the San Antonio River in the southeastern section of Bexar County, Texas. This location lies south of the Balcones
Escarpment in the Gulf Coastal Plain physiographic region (Black 1989). The area is part of the Tamaulipan province (Blair 1950) and is characterized by brushland dominated by thorny brush (Black 1989). The geology of the project area is identified as fluviatile terrace deposits comprised of gravel, sand, silt, and clay (Barnes 1983). The soil, Karnes loamy clays, are a component of the Patrick series of the Venus-Frio-Trinity

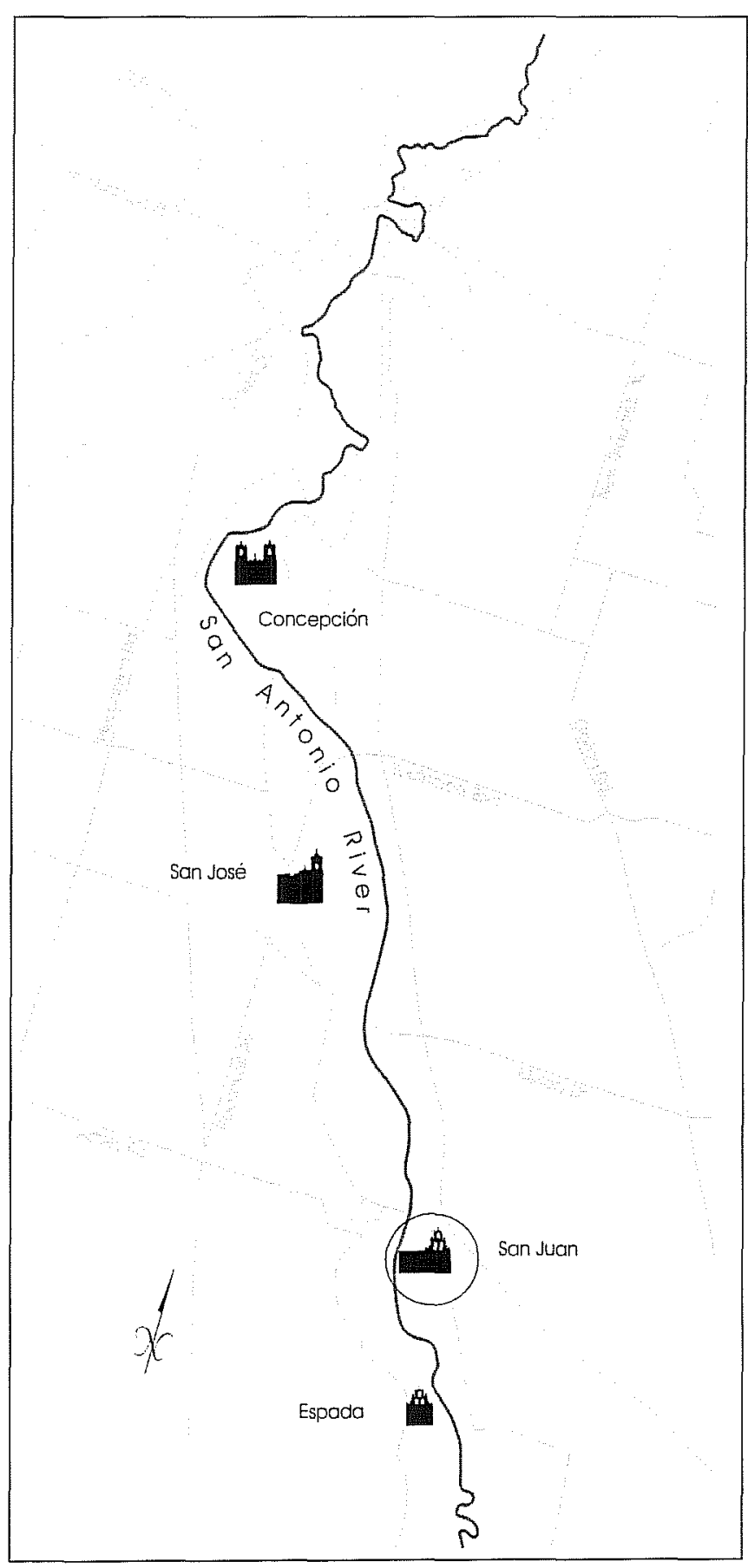

Figure 1. Location of Mission San Juan Capistrano. 
associaton (Turner 1988). The character of the soils on the site is calcareous loam to light clay loam over stratified alluvium.

\section{Previous Investigations}

Extensive archaeological investigations have been conducted at Mission San Juan Capistrano. A total of ten archaeological projects have been conducted thus far; the first performed by the Works Progress Administration (WPA) in 1933, and this project, the most recent, by the Center for Archaeological Research (CAR). The archaeological investigations can be categorized into three groups:

1) Those conducted in the 1930 s by the WPA, which centered its work on restoring and locating subsurface walls.

2) The extensive excavations directed by Mardith Schuetz and funded largely by the Catholic Archdiocese of San Antonio (Schuetz 1968, 1974, 1980a).

The investigations were necessitated by restoration plans for certain structures within the mission complex. Valuable information on the building sequence at Mission San Juan and building techniques was obtained during these projects.

3) Other archaeological investigations at San Juan are comprised of a historical and archaeological survey by the Texas Historical Commission (Scurlock et al. 1976), an architectural study (Scurlock 1976), and three cultural resource management (CRM) projects conducted by the Center for Archaeological Research (Turner 1988, Fox 1993, and the current project). The CRM projects were brief and the recovery of archaeological data was confined to areas of the mission which were impacted by construction activities.

Of importance to the current investigation is the previous identification of midden deposits located along, and north of the north wall of the compound. In 1986, an undisturbed midden deposit which extended along the exterior north wall (east of the gate) was documented (Turner 1988). The midden had accumulated from about the mid-eighteenth century into the twentieth century. Three occupation periods were identified on the basis of recovered artifacts:

1) Late nineteenth century to modern

(0-20 cm bs).

2) $1850 \mathrm{~s}$ to $1930 \mathrm{~s}(20-40 \mathrm{~cm} \mathrm{bs})$.

3) 1756 to $1830 \mathrm{~s}(40-60 \mathrm{~cm} \mathrm{bs})$.

The horizontal extent of this midden has yet to be determined. In 1974, a drainage ditch was deepened north of the north compound wall. The dirt was screened, and numerous artifacts including over 1,000 faunal specimens were recovered (Scurlock et al. 1976). While the stratigraphic context of the cultural material was disturbed (due to trenching), it was suggested that future testing in this area could possibly determine stratigraphic and temporal control of the artifacts comprising this midden (Scurlock et al. 1976).

\section{Methodology}

\section{Field Methodology}

Three units, each measuring 3' x 3', 14 shovel tests, and one backhoe trench were excavated within the the proposed service drive right-of-way (Figure 2).

Units (1-3) were dug in six inch arbitrary levels using both shovels and trowels. Units 1 and 3 were excavated to a depth of 24 inches below ground surface (bs) and Unit 2 was excavated to 36 inches below ground surface.

Shovel tests (1-14) were approximately 12 inches in diameter and were excavated in six inch arbitrary levels to a minimum depth of 20 inches and a maximum depth of 33 inches below surface.

Excavated soil was screened through 1/4-inch wire mesh and all cultural material was collected and brought back to the CAR laboratory for analysis. Information pertinent to the individual unit or shovel test (e.g., artifacts collected, soil color and texture) was recorded on standard CAR shovel test and unit forms. Artifact 


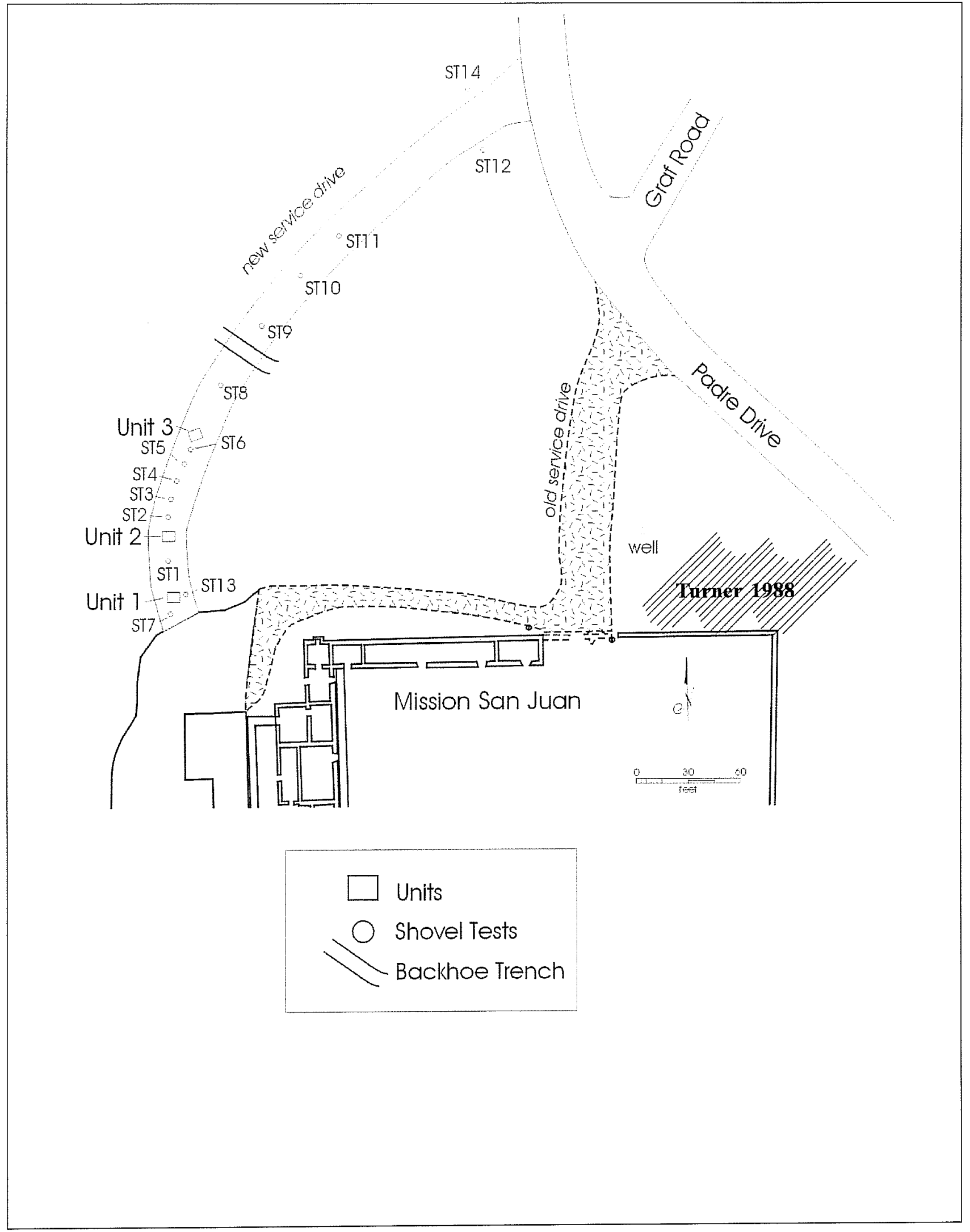

Figure 2. Area of investigation at Mission San Juan Capistrano. 
bags were assigned lot numbers and a standard CAR lot-number form was used to record the provenience information and number of bags generated in the field for each lot number.

One 24 foot backhoe trench was excavated perpendicular to the proposed service drive (Figure 2). The trench was dug to a depth of 32 inches bs by a National Park Service operator using a one foot wide bucket and the excavation was monitored by a staff archaeologist. Photographs were taken with a Canon Sure Shot camera using color print/slide film. All photographs were recorded on standard CAR forms. The location of the units and shovel tests were mapped using a compass and measuring tape.

\section{Laboratory Analysis}

Cultural materials were brought to the CAR laboratory to be washed, labeled, analyzed and curated. For analysis the artifacts were sorted into broad categories which included: ceramics, glass, metal objects, unidentified metal objects, personal, building materials, hardware, lighting materials, plastic, bone, shell and lithics. Ceramics were then further subdivided as to type (e.g., Goliad Ware, Lead-glazed, decorated and undecorated Whiteware, and Stoneware). Glass fragments were further subdivided by color. Lithic material was typed by flakes, bifaces, and cores. All artifacts, field forms, notes, maps, and photographs were curated in archival quality (acidfree) containers. These were labeled, inventoried, and placed in CAR's permanent shelving.

\section{Results}

\section{Test Unit 1}

Test Unit 1 (TU 1) is located at the far southern end of the proposed service drive, near the existing parking area (Figure 2). The area around TU 1 appears to have been previously cut, possibly during the construction of the parking area or to provide drainage away from the mission. A relatively recent cement drainage gutter runs east/west in this area and appears to terminate approximately 33 feet east of Unit 1 . This drain was not encountered during excavation of the units or shovel tests. The soil in Unit 1 consists of a relatively homogenous very dark gray (10YR 3/1) sandy clay loam, with only a slight change in color (very dark grayish brown 10YR 3/2) occurring at approximately 7-8 inches below the ground surface. Several small tree roots and charcoal inclusions were observed in Levels 2 (6-12" bs) and 3 (12-18" bs).

Cultural material from primarily the nineteenth and twentieth centuries was found mixed throughout Levels 1 through 4 (Table 1). This consisted of ceramics, glass, metal, building materials and plastic. Two Colonial ceramic sherds were recovered from Level 3, one is typed as Goliad ware and the other as an unglazed-black burnished ware. In addition, a Colonial-style scissor handle fragment was recovered from Level 4. Lithic material from this unit includes: a sandstone disc and five flakes from Level 1, a core and a biface fragment from Level 2, and two flakes from Level 3. Several examples of the sandstone disc, referred to as a cuatro, have been recovered from Mission San Juan (Schuetz 1969). Total artifact counts by level demonstrate an increase in cultural material in Levels 3 and 4 (Table 1). Several of the artifact categories show an increase in cultural material in Levels 3 and 4 due primarily to the large number of bone fragments present in these two levels (Table 1). At the base of Level 4, concrete fragments were observed in the northern half of the unit, extending from the northeast to the northwest corner.

\section{Test Unit 2}

Test Unit 2 (TU 2) lies approximately 30 feet north of TU 1 (Figure 2). The area in which TU 2 is located is about 3 feet higher in elevation than the area where TU 1 is located. Beneath the upper three inches of dark topsoil (O horizon), the soil in TU 2 consisted of a homogenous brown (10YR 5/3) silt loam, changing only minimally in color at approximately 30 inches bs to a slightly lighter grayish brown. The texture, a silt loam, remained consistent throughout Levels 16. Pea-sized rounded pebbles and angular chunks of limestone and sandstone, eight inches in length, made up approximately 30 percent of the matrix in Level 1 . 
Table 1. Artifacts recovered from Test Units

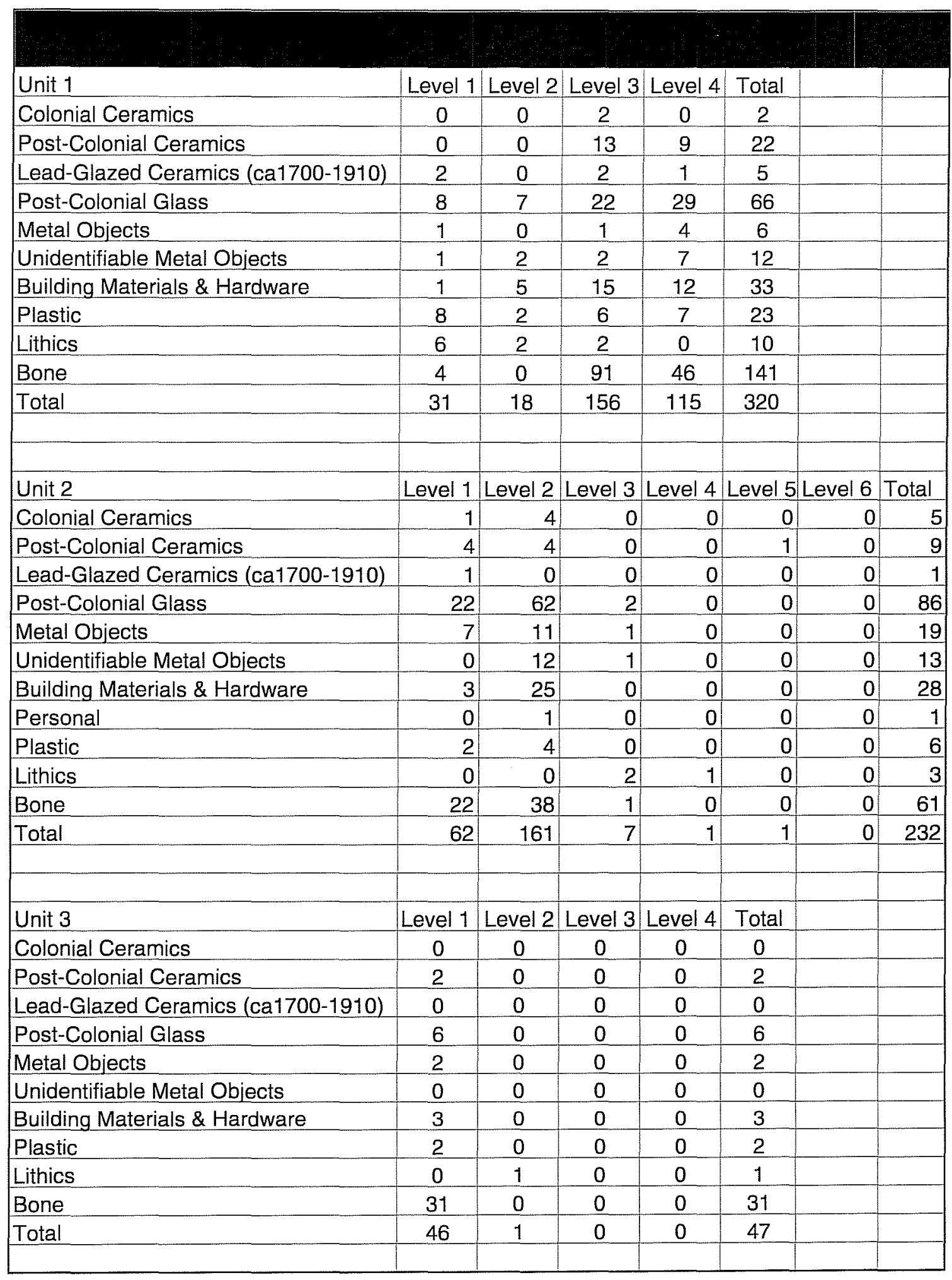


Tree roots, an ashy charcoal deposit and 25 percent gravels were noted in Level 2. Larger tree roots and a decreased quantity of pea-size to eight-inch gravels was observed in Level 3 (12-18" bs). These same gravels continued throughout Level 4 , and, at roughly 18 inches bs - a chunk of concrete $(6 \times 8 \times 2$ inches) was observed in close association with dense smooth limestone cobbles (2-4 inches in diameter) in the southeast corner of the unit. It was noted that the concrete looked like it was poured into a round hole. Level 5 contained approximately 30 percent rounded river gravels ranging in size from $1 / 4-2 \frac{1}{2}$ inches in diameter. Bedrock was encountered in the northwest corner of this unit at the bottom of Level 5 ( $30^{\prime \prime} \mathrm{bs}$ ). Two to three inches into Level 6 (32" bs) bedrock extended across the entire unit.

Artifacts recovered from TU 2 indicate subsurface disturbance through Level 4 (Table 1). A mixture of Colonial and post-Colonial materials were recovered from Levels 1-3, and a chunk of concrete was observed in Level 4. Colonial period ceramics include: one Goliad ware sherd from Level 1; and two Goliad ware, one unglazed (red-burnished) sherd, and one tin glazed sherd from Level 2. Nineteenth and twentieth century materials are largely represented in Levels 1 and 2. Total artifact counts by level demonstrate an increase in post-Colonial materials in Level 2. This is due largely to the numerous glass fragments present in that level. A total of seven artifacts were recovered from Level 3 showing a dramatic decrease in artifacts. The cultural material in Level 3 consists of two postColonial glass fragments, aluminum foil, an unidentifiable metal fragment, two lithic flakes, and a bone fragment. The only evidence of cultural material present in Level 4, (in addition to the chunk of concrete) was a broken obsidian flake. This broken flake measured 1.5 $x 1 \mathrm{~cm}(0.6 \times 0.4 \mathrm{in})$. Level 5 contained one small porcelain ceramic sherd and Level 6 was void of cultural material.

\section{Test Unit 3}

Test Unit 3 (TU 3) is approximately 70 feet north of TU 2 (Figure 2). This area appears relatively undisturbed, however, homes had been present north of the mission until they were removed by the National Park Service. The soil in TU 3 consists of a homogenous dark grayish brown (10YR 4/2) silt loam, with a slight color change to grayish brown (10YR 5/ 2 ) occurring at 18 inches bs. The soil of TU 3 is very similar to that observed in TU 2 . Artifacts recovered from TU 3 indicate that cultural material is basically confined to Level 1 (one chert flake was collected from Level 2). Cultural material recovered from Level 1 includes: post-Colonial ceramics, glass, metal objects, building materials, plastic, and bone. No Colonial artifacts were collected from Level 1 . The unit was terminated at 24 inches bs.

\section{Backhoe Trench}

The backhoe trench is located approximately 45 feet north of TU 3 (Figure 2). It was placed perpendicular to the proposed service road. The 24 foot-long backhoe trench was dug to a depth of 32 inches bs before encountering bedrock. A fragment of patinated clear glass was the only cultural material observed in the walls and no artifacts were observed in the backdirt. With the exception of a three inch lens of old road base located at the eastern end of the trench, the soil consisted of a light gray (10YR 7/2) loam with less than 5 percent gravels from ground surface to the base of the trench.

\section{Shovel Tests}

\section{Shovel Tests 1-6, and 8-10}

Shovel tests (STs) 1-6, and 8-10 were concentrated in the southern part of the proposed service drive rightof-way (Figure 2). These shovel tests contained little in the way of cultural material. The soil appeared relatively homogenous (loam, silty loam, or silty, sandy loam) throughout the shovel test levels in this area. Soil colors include browns (10YR 4/2, 10YR 5/3, 10YR 5/4, 10YR 6/3), and a light brownish gray (10 YR 6/2).

Five of the shovel tests (STs 3, 5, 6, 8, and 9) contained cultural material only in the first level ( $0-6$ " bs). Among these were: one post-Colonial handpainted whiteware sherd, one plain green earthenware sherd, two clear glass fragments, building materials (window glass, 
concrete, clay tile fragment, mortar with portland cement), one piece of plastic, and 3 lithic flakes. In ST 1, Levels $1-3$ contained 28 fragments of post-Colonial glass, 4 bone fragments, one clothespin spring, and a machinery part. In ST 2, only Level 2 contained cultural material. This consisted of one post-Colonial undecorated whiteware sherd, two fragments of clear bottle glass, nine fragments of window glass, one wire nail, and one piece of plastic. ST 10 contained five artifacts in Levels 1 and 2. These items include: one fragment of post-Colonial clear glass, one wire nail, two fragments of window glass, and one lithic flake. ST 4 was void of cultural material.

\section{Shovel Test 11}

Shovel test 11 (ST 11) is located approximately 30 feet north of ST 10. The soil in ST 11 is a brown (10YR 4/ 3) loam in Levels 1-4. Cultural material was not observed in Level 1; however, artifacts were recovered from Levels 2 and 3 . These include: 34 post-Colonial whiteware, earthenware, and porcelain ceramics; 45 fragments of clear and colored post-Colonial glass, 13 wire nails, two fragments of window glass, 24 unidentifiable metal fragments, a lithic flake and one bone fragment. Here, the largest artifact category was glass, followed by ceramics and no Colonial artifacts were recovered. ST 11 was terminated at 20 " below surface.

\section{Shovel Tests 7 and 13}

Shovel tests 7 and 13 (STs 7 and 13) were excavated at the far southern end of the proposed service drive near the existing parking area and in proximity to TU 1 (Figure 2). The soil in these two shovel tests was similar to that observed in TU 1 . In ST 13, the soil was a very dark grayish brown (10YR 3/2) sandy clay loam in Levels 1-4. The soil in ST 7 (Levels 1 and 2) was a very dark grayish brown (10YR 3/2) clay loam with a change occuring at 12 " bs (Level 3 ) to a dark grayish brown, sandy clay loam. The soil of Level 3 continued to a depth of 17 inches bs where a yellowish brown, hard clay loam was encountered. Level 4 was comprised of the yellowish brown clay loam which included some mottles of dark gray and orangish clay.
Even though ST 7 and ST 13 are relatively close in proximity (separated by approximately 7 feet) a difference in the density of artifacts by level was observed. In ST 7, post-Colonial artifacts are confined to Levels 2 and 3. In ST 13, post-Colonial artifacts are present in all four levels. Cultural material from these two shovel tests includes: four post-Colonial undecorated whiteware sherds, 13 fragments of clear and colored glass, two cut nails, two wire nails, 13 window glass fragments, one piece of cement mortar, three clay tile fragments, 8 lithics, and 12 bone fragments.

\section{Shovel Tests 12 and 14}

Shovel tests 12 and 14 (STs 12 and 14) were placed in the proposed gateway area (Figure 2). They were dug to a depth of 33 inches bs and 30 inches bs, respectively. The soil in Levels 1 and 2 of ST 12 was a dark gray (5YR 4/1) sandy loam. This soil graded into a brown (10YR 5/3) sandy loam in Level 3, a light gray (7.5 YR 7/1) sandy loam with caliche mottling in Level 4, to a pinkish white (7.5 YR 8/2) sandy loam with heavy caliche present in Levels 5 and 6. The soil in Levels 1-3 of ST 14 was a brown (7.5 YR 4/2) loam. Gravels were noted in Level 3 beginning at 13 inches bs. In Level 4, a soil change to a brown (10YR 5/3) sandy loam occurred and caliche was observed at approximately 18 inches bs. The brown sandy loam and caliche continued into Level 5 (24-30 inches bs) where the unit was terminated.

Cultural material extended into Level 3 in ST 12 and into Level 2 in ST 14. Artifacts from both shovel tests included: post-Colonial ceramic sherds, post-Colonial glass, metal objects, building materials and hardware, bone, and two shell buttons. With the exception of the two shell buttons recovered from Level 1 in ST 14, cultural material was largely comprised of modern clear glass fragments and wire nails. No Colonial artifacts were recovered from either shovel test. 


\section{Artifacts}

\section{Ceramics}

Excavation of three test units, 14 shovel tests, and one backhoe trench within the proposed service drive rightof-way (ROW) resulted in the recovery of 930 artifacts. Descriptions of diagnostic pieces from each artifact category are given here. A provenienced table of all recovered artifacts is presented in Appendix $\mathbf{I}$.

Eighty-nine ceramic sherds were recovered during the testing portion of the project (Table 2). Of the ceramics, 13 are Colonial-period ceramics which are commonly found at Spanish sites in and around the San Antonio area. The Colonial sherds include six lead-glazed, one tin-glazed, four Goliad, and two burnished.

Goliad ware has a distinctive red brown to dark brown color on the exterior and usually has a black core, due to low firing temperatures. It contains bone tempering and appears identical to the Leon Plain ceramics of the late-Prehistoric period in South Texas. Spanish Colonial artifact inventories in the San Antonio and Guadalupe River valleys are dominated by this ceramic type, strongly suggesting that it originated among the Native Americans of the South Texas area (Fox et al. 1976:67). The unglazed burnished ware appears to be a direct descendant of pre-Columbian traditions in Mexico. A burnished ware with red body (sometimes also found in black) commonly occurs in Spanish Colonial sites.

Tin-glazed wares found on Spanish sites reflect primarily eighteenth century, and early-nineteenth century occupation. The decorative patterns of tin glazed ware underwent frequent changes through time, making this ceramic type useful for dating purposes. Unfortunately, the sherd recovered is too small to identify its decorative type.

Six lead-glazed ceramic sherds were recovered during testing. Given the relatively broad temporal span of lead-glazed ceramics, affiliation with the Colonial period cannot be demonstrated. Certainly, lead-glazed ceramics decline in popularity during the nineteenth century suggests their Colonial-period association.
The majority of ceramics $(n=66)$ consist of whiteware sherds, of which 45 are undecorated (Table 2). These whiteware sherds are indicative of the nineteenth century and include the decorative types of handpainted, sponge, banded, edgeware, and decal. British-made white-bodied wares began to appear in this area in the early 1830 s. However, it was not until after the Civil War that American potteries began to be represented on San Antonio sites, at which time most of the whitewares were Ironstone or its equivalent.

The presence of one stoneware, one yellowware, and seven porcelain sherds reflect nineteenth and earlytwentieth century occupation of the site. Stoneware is a dense, hard ceramic with a white, tan or gray paste. Vessels made of this ware were used for food preparation and storage. In the late-nineteenth and early-twentieth century, yellowware was used for kitchen and utility vessels such as mixing bowls and pie plates available to housewives through mail-order catalogs and hardware stores. The porcelain sherds in this collection probably originated in Europe, where most of the porcelain was made until late in the nineteenth century. Families often had just a few pieces such as teacups and saucers or dessert plates, which were saved for special occasions. Lastly, one modern flower pot sherd was recovered during this project.

As indicated in Table 2, Colonial period ceramics were recovered from Unit 1, Levels 1-4 and Unit 2, Levels 1 and 2 . These sherds were from context that also included late nineteenth- and early twentiethcentury ceramics and do not represent intact Colonial period deposits.

\section{Glass Containers}

Two-hundred and eighty-one fragments of glass containers of various colors were recovered. The glass found on Colonial sites in San Antonio is nearly always limited to olive-green wine bottle glass. The fact that the majority of the fragments found in the shovel tests and units were of clear and colored glass, demonstrates that the artifacts are primarily derived from postColonial occupation of the site and that any Colonial glass was from mixed context. 
Table 2. Ceramic types

\begin{tabular}{|c|c|c|c|c|c|c|c|c|c|c|c|c|c|}
\hline & \multicolumn{4}{|c|}{ Colonial Period } & \multicolumn{9}{|c|}{ Post-Colonial } \\
\hline 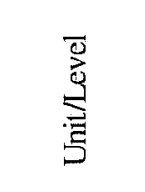 & 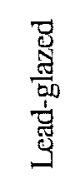 & 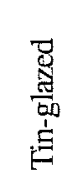 & $\frac{\text { 멸 }}{\frac{8}{8}}$ & 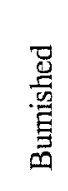 & 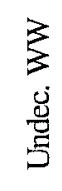 & 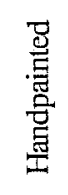 & $\begin{array}{l}0 \\
\text { 品 } \\
\text { क }\end{array}$ & 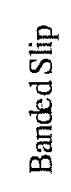 & $\begin{array}{l}\stackrel{8}{8} \\
\stackrel{5}{5} \\
\text { 畐 }\end{array}$ & $\begin{array}{l}\overline{8} \\
8\end{array}$ & 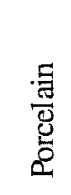 & 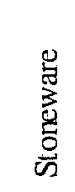 & 尊 \\
\hline $1 / 1$ & 2 & & & & & & & & & & & & \\
\hline $1 / 3$ & 2 & & 1 & 1 & 7 & 1 & 2 & 1 & & & 1 & 1 & \\
\hline $1 / 4$ & 1 & & & & 4 & 1 & 3 & & 1 & & & & \\
\hline $2 / 1$ & 1 & & 1 & & & 1 & & 1 & 1 & & 1 & & \\
\hline $2 / 2$ & & 1 & 2 & 1 & & & & & 3 & & & & \\
\hline $2 / 5$ & & & & & & & & & & & 1 & & \\
\hline $3 / 1$ & & & & & 1 & & & & & 1 & & & \\
\hline ST $2 / 2$ & & & & & 1 & & & & & & & & \\
\hline ST 3/1 & & & & & 1 & & & & 1 & & & & \\
\hline $\mathrm{ST} 11 / 2$ & & & & & 16 & & & & 1 & & 2 & & \\
\hline ST $11 / 2 \& 3$ & & & & & 5 & & & & 2 & 1 & 2 & & \\
\hline ST $11 / 3$ & & & & & 5 & & & & & & & & \\
\hline ST $12 / 1$ & & & & & 1 & & & & & & & & \\
\hline ST $13 / 4$ & & & & & 4 & & & & & & & & \\
\hline ST 14/1 & & & & & & & & & & & & & 1 \\
\hline Total & 6 & 1 & 4 & 2 & 45 & 3 & 5 & 2 & 9 & 2 & 7 & 1 & 1 \\
\hline
\end{tabular}

\section{Unidentifiable Metal}

Unidentifiable metal fragments numbering 56 were recovered. The majority of the fragments tend to represent disintegrated tin cans and other thin iron objects.

\section{Metal Objects}

Thirty-two identifiable metal objects were recovered. They consist primarily of crown bottle caps and fragments of aluminum foil. Also included is a jar lid, foil capliner, can key, two pull-tabs, pencil eraser top, pouring spout, clothespin spring, and a shotgun shell. 


\section{Miscellaneous}

One carbon rod from an arc light, measuring approximately 2 inches in length and $1 / 4-$ inch in diameter was recovered. The base of the rod was intact and the entire rod was coated in a green residue (copper sheath?) to within five-sixteenths of an inch of its tip. Eighty-three such carbon rod fragments were recovered from the Alamo Plaza project (Fox 1992). Fox reports that "the San Antonio Electric Company, chartered February 9, 1881, began operations in March 1882 by supplying 10 arc lights on Alamo Plaza" (Fox 1992:64).

\section{Building Materials and Hardware}

One hundred and forty eight artifacts consisting of building or construction materials and hardware were collected. These include: 56 wire nails, seven cut nails, 42 window glass fragments, and various other hardware and construction materials (e.g., staples, wire, mortar, concrete, clay and brick and plastic tile fragments). All of the nails recovered during this project are either cut nails which date generally to the nineteenth century or wire nails which did not reach the San Antonio area until the very end of the nineteenth century and the early portion of the twentieth century. No hand-forged Colonial nails were found. The greatest proportion of the nails was of the wire variety.

\section{Personal Objects}

A metal scissor handle fragment was recovered from Unit 1, Level 4. It is very similar in shape and style to the scissors brought up from Mexico and distributed to the Mission natives during the Colonial period (Anne Fox, personal communication). A black plastic, 5-hole button was recovered from Unit 2, Level 1; and the base of a pair of porcelain doll legs was recovered from Unit 2, Level 2. Two shell buttons were recovered from ST 14, Level 1. One is badly fragmented and burned, and the other is a complete 4-hole button.

\section{Arms}

One 12 gauge shotgun shell (Peters League No. 2) was recovered from ST 12, Level 3.

\section{Lithic Artifacts}

Twenty-nine lithic artifacts were recovered during the testing project. Included among these are 22 chert flakes, one core, one biface fragment, one obsidian flake, and three pieces of chert shatter. A sandstone disc, similiar to the gaming stones described by Schuetz (1969:71), was also found.

Although the obsidian flake was recovered from mixed context in Unit 2, the presence of obsidian at mission sites in south-central Texas is unusual. Therefore, the obsidian was sent for geologic source analysis. As detailed in Appendix III, it was determined that this flake is from a raw material source in Mexico. 


\section{Vertebrate Faunal Remains}

\author{
by Barbara A. Meissner
}

A total of 259 bones and bone fragments, weighing a total of $280.04 \mathrm{~g}$, were recovered during this project. All bones were washed, and allowed to dry, and were then weighed and identified to the lowest possible taxonomic level, using the comparative collection at the CAR laboratory and several references (Gilbert 1990; Olsen 1964, 1968; Schmid 1972). When bone could be identified only to class (mammal, bird, etc.,) an estimation of animal size was made when possible. Table 3 lists all bone, identified to lowest possible taxon. Additional observations include evidence of butchering, (butcher mark type and count); type of bone breakage (was bone broken while fresh or dry?); evidence of exposure to heat; evidence of exposure to weathering; and evidence of animal gnawing. A complete provenienced list of bone, including these observations is included in Appendix II.

The bone was, for the most part, highly fragmented. Only 17 (6.56 percent) could be identified to the genus taxonomic level. All are animals commonly found in historic sites in South Texas. One bone of particular interest is a metatarsal which closely resembles drawings of bear (Ursus sp.) metapodia in Gilbert (1990:68) and Schmid (1972:137). However, as bear is not in the comparative collection at $\mathrm{CAR}$, positive identification of this bone was not possible. In any case, although bear is relatively rare in historic sites in the region, it has been identified in a bone bed excavated just outside the west wall of Mission San Antonio de Valero (the Alamo), in downtown San Antonio (Meissner 1998), and in an excavation at Mission San José y San Miguel de Aguayo (Davidson and Clark 1978).

Butcher marks observed are shown in Table 4. Bone cut with a hand saw is a rough indicator of nineteenth century butchering, as machine saws were becoming more common shortly after the turn of the century. Eight of the 9 bones which had saw marks were found in ST 14, and the other saw-cut bone was from ST 11 (see Appendix II). The 8 saw-cut bones from ST 14 were the only bones in the collection which showed evidence of gnawing by a canid. No rodent gnawing was observed.
Only three bones showed evidence of extensive weathering. This is an indication that the majority of the bone was buried shortly after it was discarded, and had not been exposed to atmospheric weathering. Seven bones showed evidence of smoke staining, but only 1 bone had been calcined, an indication of long exposure to intense heat.

This small collection is typical of vertebrate faunal remains found scattered in sediments around a historic site. Although the nine saw-cut bones are probably post-Colonial in age, there is no evidence to show the age of other bone in the collection. Only 30 (11.58 percent) showed evidence of having been broken while the bone was fresh, however the nature of bone breakage could not be determined in almost half the collection (44.79 percent, $n=116$ ). Thus, while the highly fragmented nature of the bone may be an indication of intensive processing of the bone, there is some evidence that most breakage is the the result of postdepositional taphonomic factors.

\section{Discussion}

Shovel tests 7 and 13, and Unit 1 demonstrate that a trash deposit is present in this part of the project area. The trash deposit is primarily represented by postColonial artifacts indicating that it is mainly related to late nineteenth and early twentieth century occupation of the mission. The Colonial-period artifacts present in this trash deposit represent only 6 percent of the total assemblage from Unit 1 and these artifacts were found in mixed context.

The artifacts recovered from Unit 1, ST 7 and ST 13, demonstrate that this trash deposit is a result of postColonial mission occupation. Given the great amount of human activity which has surrounded the mission grounds both in the past, and at the present time, it is not surprising that a minimal number of Colonial artifacts are found in this trash deposit. Based on recovered cultural material, the trash deposit recorded during the present investigation appears to be unrelated to the Colonial deposits documented by Turner (1988) and Scurlock et al. (1976).

Five Colonial-period ceramic sherds were recovered from Unit 2 (one in Level 1, and four in Level 2). 
Table 3. Taxon identification

\begin{tabular}{|c|c|c|c|c|c|c|}
\hline Taxon & Common Name & Count & $\%$ & Weight $(\mathrm{g})$ & $\%$ & Notes \\
\hline Mammalia & Mammals & & & & & \\
\hline Artiodactyl & Deer/goat/sheep & 2 & $0.8 \%$ & 5.11 & $1.8 \%$ & \\
\hline Bos taurus & Cattle & 4 & $1.5 \%$ & 35.83 & $12.8 \%$ & \\
\hline Bovinae & Cattle or bison & 3 & $1.2 \%$ & 7.26 & $2.6 \%$ & \\
\hline Canis cf. familiaris & Domestic dog & 1 & $0.4 \%$ & 0.14 & $0.0 \%$ & \\
\hline Capra/Ovis & Goat or sheep & 1 & $0.4 \%$ & 2.90 & $1.0 \%$ & $\begin{array}{l}\text { Difficult to differentiate in } \\
\text { fragmented samples }\end{array}$ \\
\hline Sus scrofa & Domestic pig & 4 & $1.5 \%$ & 10.25 & $3.7 \%$ & \\
\hline Ursus? & Possible bear & 1 & $0.4 \%$ & 4.30 & $1.5 \%$ & $\begin{array}{l}\text { No comparative available, but } \\
\text { closely resembles drawings } \\
\text { (Gilbert 1990:68; Schmid } \\
\text { 1972:137) }\end{array}$ \\
\hline \multicolumn{7}{|c|}{ Unidentified Mammals } \\
\hline & \begin{tabular}{|c|} 
Medium \\
\end{tabular} & 1 & $0.4 \%$ & 0.28 & $0.1 \%$ & Dog-sized \\
\hline & Large & 10 & $3.9 \%$ & 18.71 & $6.7 \%$ & Deer/goat sized \\
\hline & Very large & 26 & $10.0 \%$ & 88.05 & $31.4 \%$ & Cattle/bison sized \\
\hline & Size not determined & 188 & $72.6 \%$ & 96.29 & $34.4 \%$ & \\
\hline & Total Mammals & 241 & $93.1 \%$ & 269.12 & $96.1 \%$ & \\
\hline \multicolumn{7}{|l|}{ Aves } \\
\hline & Unidentified Birds & & & & & \\
\hline & Large & 1 & $0.4 \%$ & 0.19 & $0.1 \%$ & Chicken-sized \\
\hline & Medium & 2 & $0.8 \%$ & 0.64 & $0.2 \%$ & Pigeon-sized \\
\hline & Total Birds & 3 & $1.2 \%$ & 0.83 & $0.3 \%$ & \\
\hline Reptilia & Reptiles & & & & & \\
\hline \multirow[t]{2}{*}{ Trionyx sp. } & Soft-shelled turtle & 7 & $2.7 \%$ & 5.79 & $2.1 \%$ & \\
\hline & Total Reptiles & 7. & $2.7 \%$ & 5.79 & $2.1 \%$ & \\
\hline Osteichthyes & Fish & & & & & \\
\hline \multirow[t]{3}{*}{ Ictalurus sp. } & Catfish & 1 & $0.4 \%$ & 2.24 & $0.8 \%$ & \\
\hline & Unidentified fish & 4 & $1.5 \%$ & 1.88 & $0.7 \%$ & \\
\hline & Total Fish & 5 & $1.9 \%$ & 4.12 & $1.5 \%$ & \\
\hline \multirow[t]{2}{*}{ Vertebrata } & Unidentified bone & 3 & $1.2 \%$ & 0.18 & $0.1 \%$ & \\
\hline & Totals & 259 & $100.0 \%$ & 280.04 & $100.0 \%$ & \\
\hline
\end{tabular}

Table 4. Observed butcher marks

\begin{tabular}{|l|c|}
\hline \multicolumn{1}{|c|}{ Butcher Mark Type } & Count \\
\hline Thick cut mark (from large knife or small hatchet, superficial) & 2 \\
Chop (from hatchet or ax, deep) & 4 \\
Hand saw cut & 6 \\
Saw cut, indeterminate (hand saw or machine saw -could not be determined) & 3 \\
\hline
\end{tabular}


However, these sherds were found in mixed context with 62 fragments of post-Colonial glass. Excluding bone fragments, the Colonial artifacts represent 2 percent of the units' artifact assemblage. This trash deposit also appears to be related to post-Colonial occupation of the mission but is not thought to be part of the same trash deposit recognized in Unit 1, as it is located approximately three feet higher in elevation.

\section{Recommendations}

Previous archaeological work at Mission San Juan has resulted in the documentation of two middens along, and north of the north compound wall. In 1974, a midden west of the north gate was documented (Scurlock et al. 1976), and in 1986 another midden east of the north gate was recorded (Turner 1988). Both of these middens contain Colonial components, which reflect mission life. However, the current archaeological testing conducted by CAR along the proposed service drive right-of-way indicates that these Colonial-period midden deposits do not extend into this area. A total of seven Colonial-period ceramics was recovered from three $3 \times 3$ foot units and 14 shovel tests. The Colonial artifacts were mixed with postColonial materials and Colonial ceramics represent only 1.1 percent of the total artifact assemblage (bone fragments were excluded from total artifact counts).

Colonial material is minimally represented within the project area and no intact Colonial deposits were observed. The documented post-Colonial trash deposits are stratigraphically disturbed reflecting a combination of nineteenth and twentieth century materials and the research potential of such deposits is considered minimal. Therefore, it is recommended that no additional archaeological investigation is required prior to the construction of the new service drive. However, given the extremely sensitive area north of the north compound wall, where intact Colonial deposits have been documented by Turner (1988), and Scurlock et al. (1976), archaeological monitoring is recommended during the removal of the pavement from the existing service road in this area. 


\section{Archaeological Monitoring at Mission San Juan Capistrano}

\author{
Rick C. Robinson
}

\section{Introduction}

Between October 4 and 7, 1999, the National Park Service (NPS), requested that a staff archaeologist from the Center for Archaeological Research (CAR) of The University of Texas at San Antonio (UTSA), be present to monitor the removal of asphalt from the existing service drive outside the north wall of Mission San Juan Capistrano (41BX5).

In compliance with section 106 of the National Historic Preservation Act of 1966 (as amended) and under the Texas Antiquities Permit 1908, a monitor from CAR was present to ensure that no significant cultural deposits would be disturbed during the road removal. Robert J. Hard, director of CAR at UTSA served as principle investigator, with $\mathrm{C}$. Britt Bousman as co-principle investigator.

\section{Research Background of Project Area}

The area of concern is the old service drive that runs parallel in an east to west direction along the north wall of Mission San Juan and a portion of Graf Road that previously entered the mission compound (Figure 2). Based on information from the Fray Delores Report of 1762, Schuetz (1968:40-42) was able to suggest that the jacal living structures were probably located in the northwestern corner of the mission. Ivey (Ivey et al. 1990:233) also suggests that the Indian quarters "built between 1762 and 1772 ran from the north gate west to the northwest corner and from there south to the present church of San Juan." Evidence of post-Colonial occupation was evident through Schuetz's excavations and deed records for the early-nineteenth century (Schuetz 1968:73-84). Ivey also suggested that post-Colonial occupation within the mission's northwest corner probably continued until 1900 or perhaps even later.
In February of 1988, David Turner of CAR conducted a series of test units at the northeastern corner outside the mission's compound wall (Turner 1988). Turner's excavations revealed that the soil layer from $0-40 \mathrm{~cm}$ contained a mixed deposit of late-nineteenth to twentieth century artifacts. Deposits from $20-40 \mathrm{~cm}$ contained a higher concentration of late-nineteenth century intermixed with early-twentieth century artifacts. However, the deeper soils at 40-60 $\mathrm{cm}$ showed a heavier concentration of late-eighteenth to early-nineteenth century artifacts (Turner 1988:8-11). Because of restrictions of the project, he was not able to determine the spatial boundaries of this midden's deposit. He was, however, able to determine that it was at least $60 \mathrm{~cm}$ deep and had a chronological framework ranging from late-eighteenth to the early-twentieth century. He concluded that the midden resulted from multiple dumping on the ground surface -as opposed to a pit excavated to receive the trash fill (Turner 1988:23). With the presence of the midden on the eastern side of the gateway, the potential existed that this cultural feature could extend to the western side of the gateway and, therefore, be within the current project area.

The access road has had an impact on the general area, but there is still a possibility that deeper levels containing intact Colonial to post-Colonial deposits may exist under the road. Additionally, the paved area of Graf Road, in front of the gateway, has not been thoroughly investigated previously, therefore, its archaeological potential is unknown.

\section{Monitoring}

The removal of the asphalt from the project area was conducted by Eddie Ramon of NPS. A backhoe was utilized in breaking up the asphalt and a thin layer of underlying roadbase. No subsurface levels were exposed except in the area of Graf Road, where small patches of a dark brown clay soil were exposed beneath the roadbase. A few artifacts (glass, ceramic sherds, broken soda bottle bottom) were collected associated with this exposed surface and were found to be of twentieth century origin. Overall the removal of the asphalt within the project area impacted no significant cultural deposits. 


\section{Summary/Recommendations}

The removal of the paved surface of Graf Road and the old service drive was conducted with the utmost care to ensure that no cultural deposits would be disturbed. No cultural deposits were uncovered during the project except on Graf Road where small patches of soil under the roadbase were exposed. The artifacts that were associated with this exposed surface clearly indicate that they are of twentieth century origin. However, it is recommended that any future subsurface excavations within the road area be monitored because of the possibility of deeper intact deposits. It is also possible that the midden identified by Turner (1988), on the east side of the gateway could also extend to the western side. Therefore, any future land modification performed within the general area north

of the compound should require testing to define the boundaries of this important feature. 


\section{References Cited}

Barnes, V. E.

1983 Geologic Atlas of Texas: San Antonio Sheet. Bureau of Economic Geology. The University of Texas at Austin.

Black, S. L.

1989 Environmental Setting. In From the Gulf Coast to the Rio Grande: Human Adaptation in the Central, South, and Lower Pecos Texas, by T. R. Hester, S. L. Black, D. G. Steele, B. W. Olive, A. A. Fox, K. J. Reinhard, and L. C. Bement, pp. 5-17. Research Series no. 33. Arkansas Archeological Survey, Fayetteville.

Black, T. III

1978 A new method for assessing the sex of fragmentary skeletal remains: Femoral shaft circumference. American Journal of Physical Anthropology 48:227-231.

Blair, W. F.

1950 The Biotic Provinces of Texas. Texas Journal of Science 2:93-117.

Davidson, B. and J. W. Clark

1978 Faunal Analysis. In Mission San José y San Miguel de Aguayo Archeological Investigations, December 1974. Office of the State Archeologist, Report No. 29, Texas Historical Commission, Austin.

Fox, A. A.

1992 Archaeological Investigations in Alamo Plaza, San Antonio, Bexar County, Texas. Archaeological Survey Report, No. 205. Center for Archaeological Research, The University of Texas at San Antonio.

1993 Archaeological Testing and Monitoring in Connection with a Drainage Project at Mission San Juan Capistrano, San Antonio, Bexar County, Texas. Archaeological Survey Report, No. 217. Center for Archaeological Research, The University of Texas at San Antonio.

Fox, A. A., F. A. Bass, Jr., and T. R. Hester

1976 The Archaeology and History of Alamo Plaza. Archaeological Survey Report, No. 16. Center for Archaeological Research, The University of Texas at San Antonio.

Francis, J. R.

1999 Non-Indian Burials at the Spanish Colonial Missions: San Juan Capistrano, San Antonio, Texas. Paper presented at the Society for Historical Archaeology 32nd Conference on Historical and Underwater Archaeology, Salt Lake City, Utah.

Genovés, S.

1967 Proportionality of the long bones and their relation to stature among Meso-americans. American Journal of Physical Anthropology 26:67-77.

Gilbert, B. M.

1990 Mammalian Osteology. Missouri Archaeological Society, Columbia, Missouri. 
Gross, K. J.

1998 Archaeological Testing and Monitoring for a Proposed Drainage Channel at Mission San Juan Capistrano, San Antonio, Texas, Archaeological Survey Report, No. 283. Center for Archaeological Research, The University of Texas at San Antonio.

Ivey, J. E., M. B. Thurber, and S. Escobedo

1990 Of Various Magnificence. The Architectural History of the San Antonio Missions in the Colonial Period and the Nineteenth Century. Volume One. National Park Service, Professional Papers No. 11, Santa Fe, New Mexico. Draft on file at the Center for Archaeological Research, The University of Texas at San Antonio.

Meissner, B. A.

1998 Analysis of the Colonial-Period Bone Bed Outside the West Wall of Mission San Antonio de Valero (the Alamo). Unpublished Master's Thesis, in preparation.

Olsen, S. J.

1964 Mammal Remains from Archaeological Sites Part I; Southeastern and Southwestern United States. Peabody Museum, Cambridge.

1968 Fish, Amphibian and Reptile Remains from Archaeological Sites, Part I: Southeastern and Southwestern United States. Peabody Museum, Cambridge.

Schmid, E.

1972 Atlas of Animal Bones for Prehistorians, Archaeologists and Quaternary Geologists. (Knochenatlas. Fur Prahistoriker. Archaologen und Ouartargeologen). Elsevier, Amsterdam.

Schuetz, M. K.

1968 The History of Mission San Juan Capistrano, San Antonio, Texas, Volume I. State Building Commission Archeological Program, Report 11, Austin.

1969 The History of Mission San Juan Capistrano, San Antonio, Texas, Volume I. State Building Commission Archeological Program, Report 11, Austin.

1974 The Dating of the Chapel at Mission San Juan Capistrano, San Antonio, Texas. Texas Historical Commission, Office of the State Archeologist, Special Report 12. Austin.

1980a History and Archeology of Mission San Juan Capistrano, San Antonio, Texas (Vol. 4). Excavation of the Convento. Manuscript on file, Texas Historical Commission, Office of the State Archeologist. Austin.

Scurlock, D.

1976 An Archeological and Architectural Tests at Mission San Juan Capistrano Church, March and April, 1975. Texas Historical Commission, Office of the State Archeologists, Special Report 21, Austin.

Scurlock, D., A. Benavides, Jr., D. Isham, and J. Clark

1976 An Archeological and Historical Survey of the Proposed Mission Parkway, San Antonio, Texas. Texas Historical Commission, Office of the State Archeologist, Archeological Survey Report 17. Austin.

Steele, D. G.

1976 The estimation of sex on the basis of the talus and calcaneus. American Journal of Physical Anthropology 45:581-588. 
Steele, D. G., and C. A. Bramblett

1988 Anatomy and Biology of the Human Skeleton. Texas A\&M University Press. College Station, Texas.

\section{Turner, D. D.}

1988 Excavations at San Juan Capistrano, 41BX5, Bexar County, Texas. Archaeological Survey Report, No. 171. Center for Archaeological Research, The University of Texas at San Antonio. 


\section{Appendix I}

List of Artifacts 


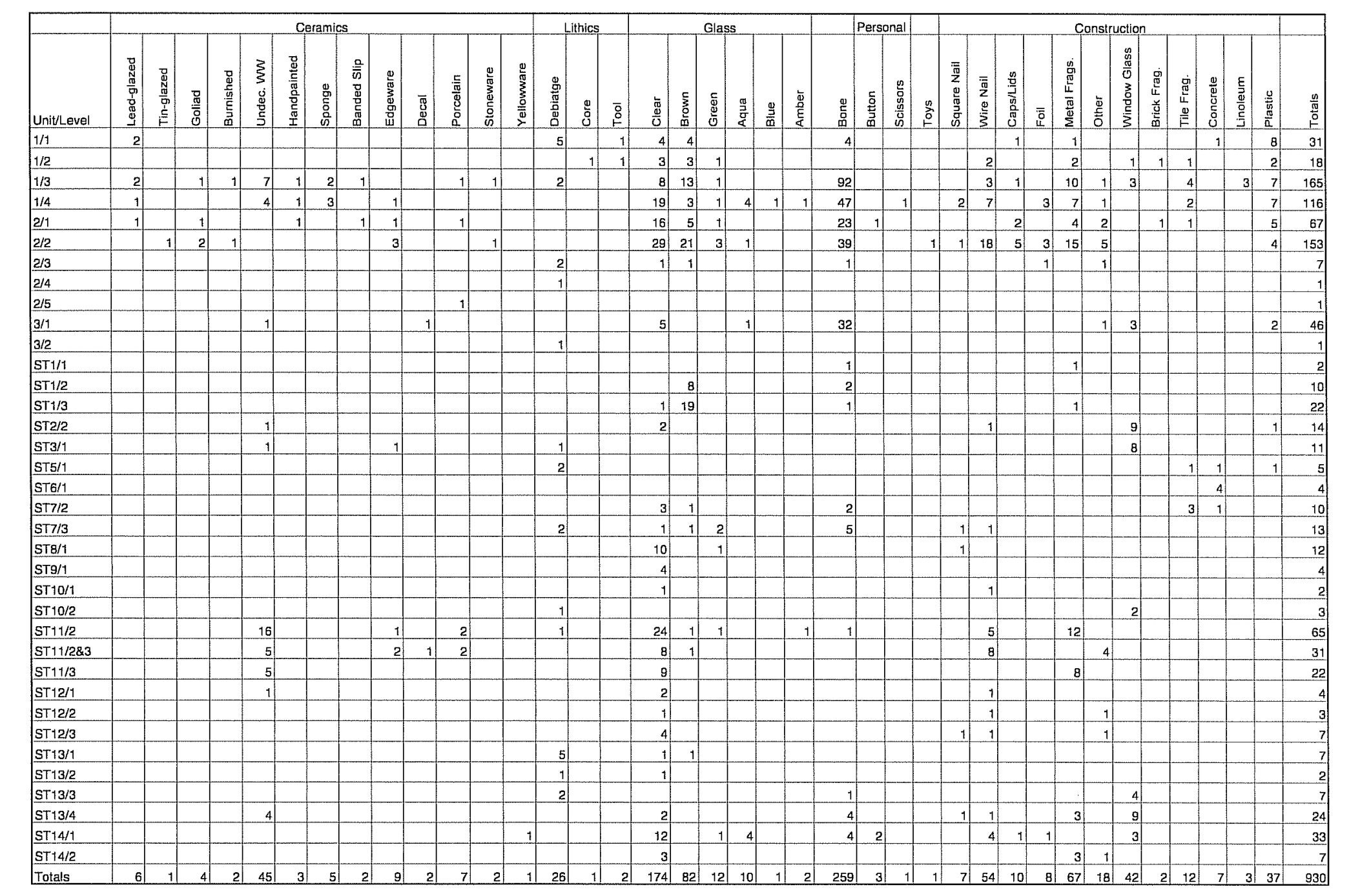


Appendix II

Faunal Data 


\begin{tabular}{|c|c|c|c|c|c|c|c|c|c|c|c|c|c|c|c|c|}
\hline & & & & & & & & \multirow{2}{*}{\multicolumn{2}{|c|}{ Butcher marks }} & & & & \\
\hline & & & & & & & & & & & & & & & & \\
\hline Prov./L & & Taxon & $\mathrm{Ct}$. & $\mathrm{WgL}(\mathrm{g})$ & Element & Portion & Side & 啹 & Type & Count & 总 & 总 & 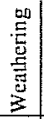 & 点 & 怨 & Notes \\
\hline ST 壮1 & 1 & Mammal--Large & 1 & 5.30 & & & $\mathrm{~N} / \mathrm{A}$ & No & 2 & 2 & 1 & 0 & $\mathrm{I}$ & $\mathrm{I}$ & 0 & \\
\hline ST 㭋 1 & 1 & Mammal--Very Large & 1 & 2.96 & & & N/A & No & & & 2 & 0 & 1 & 1 & 0 & \\
\hline ST \#1 & 2 & Mammal--Large & 2 & 1.82 & & & N/A & No & & & 2 & 0 & 1 & 1 & 0 & \\
\hline ST \#11 & 2 & Bos taurus & 1 & 13.39 & Hunenus & Dinphysis & N/A & No & 5 & 2 & 1 & 0 & $\mathrm{I}$ & I & 0 & Round steak bone \\
\hline ST H13 & 3 & Mammal & 1 & 0.51 & & & N/A & No & & & 2 & 0 & $\mathrm{I}$ & 1 & 0 & \\
\hline ST \#13 & 4 & Capra/Ovis & 1 & 2.90 & Metapodial & $\begin{array}{l}\text { Fragment of } \\
\text { diaphysis }\end{array}$ & N/A & No & & & 2 & 0 & 1 & 1 & 0 & \\
\hline ST\#13 & 4 & Mammal--Very Large & 3 & 11.75 & Long bone & Fragment & $\mathrm{N} / \mathrm{A}$ & No & & & 2 & 0 & $\mathrm{I}$ & 1 & 0 & \\
\hline ST \#14 & 1 & Bos taurus & 2 & 7.44 & Humerus & Diaphysis & $\mathrm{N} / \mathrm{A}$ & No & 4 & 2 & 1 & 0 & I & I & 2 & $\begin{array}{l}2 \text { pieces mend. Round steak } \\
\text { bone }\end{array}$ \\
\hline ST \#14 & 1 & Mammal & 5 & 2.78 & & & N/A & No & 5 & 2 & 1. & 0 & 1 & $I$ & 2 & \\
\hline ST \#14 & 1 & Mammal & 1 & 1.54 & Rib & Fragment & $\mathrm{N} / \mathrm{A}$ & No & 4 & 1 & 1 & 0 & 1 & $\mathrm{I}$ & 2 & \\
\hline ST \#7 & 2 & Mammal & 2 & 0.68 & & & N/A & No & & & $\mathrm{I}$ & 0 & 1 & $I$ & 0 & \\
\hline ST \#7 & 3 & Mammal & 5 & 2.78 & & & N/A & No & & & I & 0 & $\mathrm{I}$ & 1 & 0 & \\
\hline Unit 1 & 1 & Vertebrate & 3 & 0.18 & & & N/A & No & & & $\mathrm{I}$ & 0 & I & $I$ & 0 & \\
\hline Unit 1 & 3 & Bos taurus & 1 & 15.00 & Molar & Almost complete & N/A & No & & & 1 & 0 & I & I & 0 & Upper 3rd molar \\
\hline Unit 1 & 3 & Bovinae & 1 & 1.51 & Cervical vertebra & $\begin{array}{l}\text { Fragment of } \\
\text { anterior } \\
\text { epiphysis }\end{array}$ & N/A & Yes & & & 2 & 0 & I & I & 0 & \\
\hline Unit 1 & 3 & cf. Sus scrofa & 1 & 2.66 & Rib & Fragmen! & N/A & No & & & 2 & 0 & 1 & 1 & 0 & \\
\hline Unit 1 & 3 & Mammal & 34 & 6.52 & & & N/A & No & & & 1 & 4 & $I$ & $\mathrm{~J}$ & 0 & \\
\hline Unit 1 & 3 & Mammal & 48 & 29.87 & & & $N / A$ & No & & & 1 & 1 & 1 & $\mathrm{I}$ & 0 & \\
\hline Unit 1 & 3 & Mammal--Large & 1 & 1.53 & $\mathrm{Rib}$ & Fragment & $\mathrm{N} / \mathrm{A}$ & No & & & 1 & 0 & 1 & 1 & 0 & \\
\hline Unit 1 & 3 & Osteichthys & 1 & 0.24 & & & N/A & No & & & 2 & 0 & 1 & I & 0 & \\
\hline Unit 1 & 3 & Sus scrofa & 1 & 1.57 & Caudal Vertebra & $\begin{array}{l}\text { All but } \\
\text { epiphyses and } \\
\text { transverse } \\
\text { processes }\end{array}$ & N/A & Yes & & & 2 & 0 & 1 & I & 0 & Epiphyses are unsealed \\
\hline Unit 1 & 3 & Sus scrofa & 1 & 5.66 & Cranium & $\begin{array}{l}\text { Fragment of } \\
\text { temporal bone }\end{array}$ & N/A & No & 3 & 1 & 3 & 0 & 1 & 1 & 0 & \\
\hline Unit 1 & 3 & Sus scrofa & 1 & 0.36 & Premolar & Fragment & $\mathrm{N} / \mathrm{A}$ & No & & & 2 & 0 & $\mathrm{I}$ & 1 & 0 & \\
\hline Unit 1 & 4. & Artiodactyl & 1 & 0.66 & Incisor & Fragment & Left & No & & & 2 & 0 & $\mathrm{I}$ & $\mathrm{I}$ & 0 & \\
\hline Unit 1 & 4 & Aves & 1 & 0.19 & Long bone & Fragment & $\mathrm{N} / \mathrm{A}$ & No & & & 1 & 0 & I & $\mathrm{I}$ & 0 & Chicken-sized \\
\hline Unit 1 & 4 & Bovinae & 1 & 4.53 & Hyoid & Fragment & $\mathrm{N} / \mathrm{A}$ & No & & & 1 & 0 & $\mathrm{I}$ & $\mathrm{I}$ & 0 & \\
\hline Unit 1 & 41 & Mammal & 31 & 12.65 & & & N/A & No & & & 2 & 1 & I & $\mathrm{I}$ & 0 & \\
\hline Unit 1 & 41 & Mammal & 5 & 4.61 & & & $\mathrm{~N} / \mathrm{A}$ & No & & & 2 & 0 & 1 & $\mathrm{I}$ & 0 & \\
\hline Unit 1 & 41 & Mammal--Very Large & 3 & 13.47 & Long bone & Fragment & N/A & No & & & 1 & 1 & $\mathrm{I}$ & $I$ & 0 & \\
\hline Unit 1 & 4 . & Mammal--Very Large & 1 & 16.17 & Long bone & Fragment & N/A & No & & & 3 & 0 & 2 & I & 0 & \\
\hline Unit 1 & 41 & Mammal--Very Large & 3 & 5.94 & & & N/A & No & & & 2 & 0 & $\mathrm{I}$ & $\mathrm{I}$ & 0 & \\
\hline Unit 2 & 1 & Artiodactyl & 1 & 4.45 & Innominate & $\begin{array}{l}\text { Frag of } \\
\text { acetabulum and } \\
\text { illium }\end{array}$ & Left & No & & & 2 & 0 & 1 & 1 & 0 & \\
\hline Unit 2 & 11 & Mammal & 1 & 1.57 & Long bone & Fragment & $\mathrm{N} / \mathrm{A}$ & No & & & 3 & 1 & $\mathrm{I}$ & 1 & 0 & \\
\hline Unit 2 & 11 & Mammal & 9 & 6.44 & & & N/A & No & & & 2 & 0 & 0 & $\mathrm{I}$ & 0 & \\
\hline Unit 2 & 1 I & Mammal--Large & 1 & 2.29 & Long bone & Fragtaent & $\mathrm{N} / \mathrm{A}$ & No & & & 2 & 0 & $\mathrm{I}$ & 1 & 0 & \\
\hline Unit 2 & 1 & Mammal--medium & 1 & 0.28 & Long bone & Fragment & N/A & No & & & 1 & 0 & $\mathrm{I}$ & I & 0 & \\
\hline Unit 2 & 11 & Mammal--Very Large & 1 & 2.98 & Rib & Fragment & N/A & No & 3 & 2 & 1 & 0 & $\mathrm{I}$ & $\mathrm{I}$ & 0 & Chop is rough-edged \\
\hline Unit 2 & 11 & Mammal--Very Large & 1 & 3.34 & Rib & Fragment & N/A & No & & & 1 & 0 & $\mathrm{I}$ & 1 & 0 & \\
\hline Unit 2 & 11 & Mammal--Very Large & $1)$ & 1.79 & Mandible & Fragment & $\mathrm{N} / \mathrm{A}$ & No & & & 2 & 0 & $\mathrm{I}$ & $\mathrm{I}$ & 0 & \\
\hline Unit 2 & 11 & Mammal--Very Large & 1 & 1.16 & Long bone & Fragment & N/A & No & & & 1 & 0 & $\mathrm{I}$ & I & 0 & \\
\hline Unit 2 & 11 & Mammal--Very Large & 3. & 3.81 & & & $\mathrm{~N} / \mathrm{A}$ & No & & & 2 & 0 & 1 & $\mathrm{I}$ & 0 & \\
\hline Unit 2 & 10 & Osteichthys & 3 & 1.64 & & & $\mathrm{~N} / \mathrm{A}$ & No & & & 2 & 0 & $\mathrm{I}$ & 1 & 0 & \\
\hline Unit 2 & 21 & Aves & 2 & 0.64 & & & $\mathrm{~N} / \mathrm{A}$ & No & & & 2 & 0 & $\mathrm{I}$ & $\mathrm{I}$ & 0 & \\
\hline Unit 2 & 21 & Bovinae & 1 & 1.22 & Incisor & Almost complete & Left & No & & & 2 & 0 & I & 1 & 0 & \\
\hline Unit 2 & 20 & Canis cf. familiaris & 1 & 0.14 & Molar & Complete & Right & Yes & & & 1 & 0 & $I$ & 1 & 0 & Deciduous lower Ml \\
\hline Unit 2 & 21 & Ictalurus sp. & 1 & 2.24 & Prefrontal & Fragment & N/A & No & & & 2 & 0 & 1 & 1 & 0 & Large fish \\
\hline Unit 2 & 21 & Mammal & 20 & 11.31 & & & N/A & No & & & $\mathrm{I}$ & 4 & I & $I$ & 0 & \\
\hline Unit 2 & 21 & Mammal--Large & 2 & 5.74 & Long bone & Fragment & N/A & No & & & 1 & 0 & I & $\mathrm{I}$ & 0 & \\
\hline Unit 2 & 21 & Mammal--Large & 1. & 0.52 & Lumbar vertebra & $\begin{array}{l}\text { Fragment of } \\
\text { distal diaphysis }\end{array}$ & $\mathrm{N} / \mathrm{A}$ & Yes & & & 3 & 0 & I & I & 0 & \\
\hline Unit 2 & 21 & Marnmal--Large & 2 & 1.51 & Long bone & Fragment & N/A & No & & & 3 & 0 & I & I & 0 & \\
\hline Unit 2 & 21 & Manmal--Very Large & 1 & 4.73 & Rib & Fragment & N/A & No & 3 & 2 & 1 & 0 & $I$ & $I$ & 0 & clean chops \\
\hline Unit 2 & 21 & Mammal--Very Large & 1 & 6.60 & Rib & Fragment & $\mathrm{N} / \mathrm{A}$ & No & 2 & 4 & 1 & 0 & I & I & 0 & \\
\hline Unit 2 & 21 & Mammal-Very Large & 1 & 2.49 & Vertebra & $\begin{array}{l}\text { Fragment of } \\
\text { centrum }\end{array}$ & N/A & Yes & & & 2 & 0 & I & I & 0 & Epiphysis unsealed \\
\hline
\end{tabular}




\begin{tabular}{|c|c|c|c|c|c|c|c|c|c|c|c|c|c|c|c|}
\hline \multirow[b]{2}{*}{ Prov/Lev. } & & & & & & & & Butch & marks & & & & & & \\
\hline & Taxon & Ct. & $\mathrm{Wgt}(\mathrm{g})$ & Element & Portion & Side & 葛 & Type & Count & 䜦 & 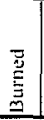 & 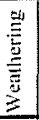 & 孟 & 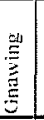 & Notes \\
\hline \begin{tabular}{|l|} 
Unit 2 \\
\end{tabular} & 2 Mammal-Very Large & 1 & 3.47 & Long bone & Frngment & $\mathrm{N} / \mathrm{A}$ & No & 3 & 2 & 1 & 0 & 1 & I & 0 & chop marks on inside of bone \\
\hline Unit 2 & 2 Mammal-Nery Large & 3 & 3.73 & & & N/A & No & & & 2 & 0 & $\mathrm{I}$ & 1 & 0 & \\
\hline Unit 2 & $2 \mid$ Mammal-Very Large & 1 & 3.66 & & & $\mathrm{~N} / \mathrm{A}$ & No & & & 2 & 0 & 1 & I & 0 & \\
\hline Unit 2 & 2 |Ursus? & 1 & 4.30 & Metatarsus & Diaphysis & Left & No & & & 2 & 0 & 1 & 1 & 0 & $\begin{array}{l}\text { No comparative available, } \\
\text { however closely resembles } \\
\text { drawings. }\end{array}$ \\
\hline Unit 2 & 3 Mammal & 1. & 0.42 & & & N/A & No & & & I & 0 & I & 1 & 0 & \\
\hline Unit 3 & 1) Mammal & 23 & 12.93 & & & N/A & No & & & 2 & 0 & I & 2 & 0 & \\
\hline Unit 3 & 1) Mammal & 2 & 1.68 & & & $\mathrm{~N} / \mathrm{A}$ & No & & & 2 & 0 & 2 & 1 & 0 & \\
\hline Unit 3 & 1) Trionix sp. & 7 & 5.79 & Plastron & Fragment & $\mathrm{N} / \mathrm{A}$ & No & & & 2 & 0 & 1 & I & 0 & \\
\hline
\end{tabular}





\section{Appendix III \\ Geologic Source Analysis of an Obsidian Artifact}




\section{Geologic Source Analysis of an Obsidian Artifact}

\author{
Thomas R. Hester, Frank Asaro, Fred H. Stross \\ and Robert Giauque
}

\section{Introduction}

During excavations at Mission San Juan Capistrano (41BX5) San Antonio, Texas in November 1997, an obsidian fragment was obtained from Unit 2, 18-24 inches (Lot 6).

The specimen (Figure 3-1) is a proximal section of a blade-like flake. At first glance, it resembles a Mesoamerican obsidian blade. However, the bulb of percussion is at one corner of the ventral surface, and it was apparently struck off as a flake. It has a single arris on the dorsal surface, with half of that surface covered in cortex. There are some nicks on one edge of the specimen, but no evidence of patterned retouch.

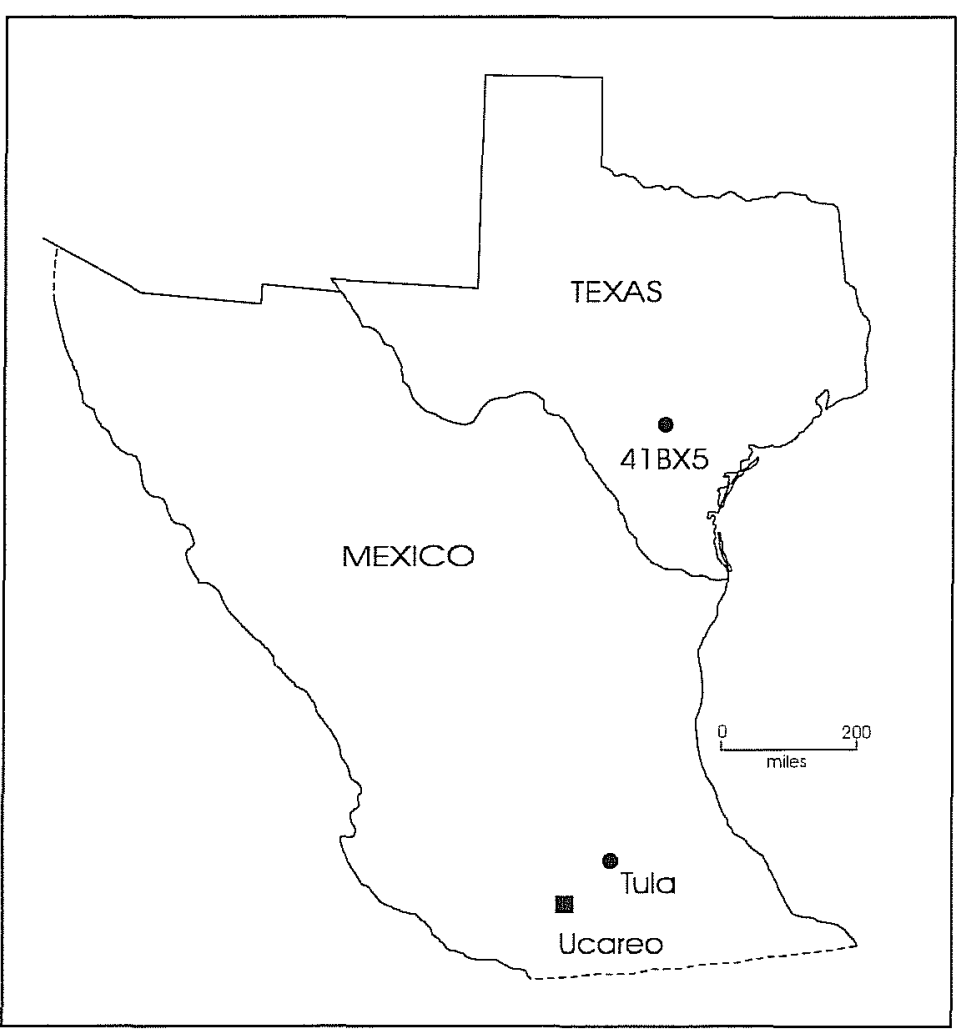

Figure 3-2. Map indicating location of Mission San Juan (41BX5), Texas in relation to Ucareo source in Mexico.
Figure 3-1. Drawing of obsidian fragment obtained from Unit 2, Mission San Juan.

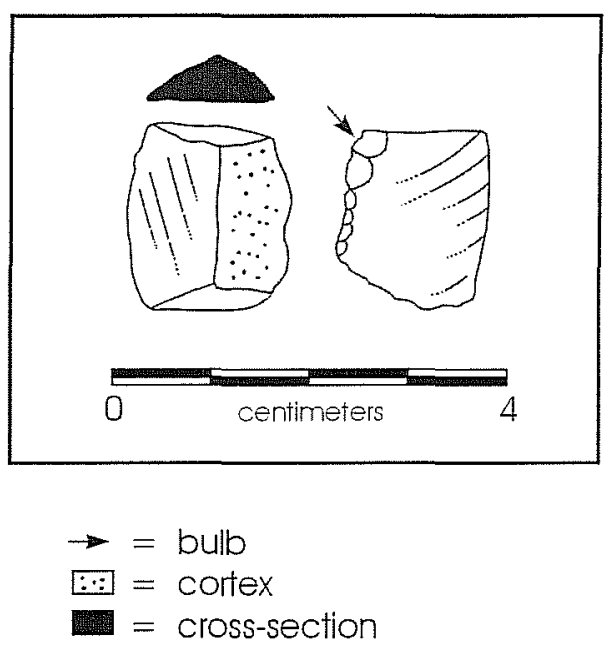

The artifact is $19.5 \mathrm{~mm}$ long, $17 \mathrm{~mm}$ wide, $5 \mathrm{~mm}$ thick, and weighs $2 \mathrm{~g}$.

Through the courtesy of Dr. Robert Hard, Director of the Center for Archaeological Research, of The University of Texas at San Antonio, the specimen was provided to Hester so that trace-elements analysis could be done in the hopes of ascertaining its geologic source. As far as the senior author knows, the flake is the only piece of obsidian that has been found in a mission context in Texas and northeastern Mexico. Since there are a number of obsidian flakes and artifacts found in Central and Southern Texas during the preceding Late Prehistoric, it seemed possible that perhaps it was of that age, rather than Spanish Colonial. Indeed, visual inspection of the piece showed it to be smoky, blue gray translucent obsidian, which Hester thought was perhaps from Malad, Idaho, source of much obsidian in the Late Prehistoric in Texas.

It is fortunate, however, that non-destructive precise $\mathrm{x}$-ray fluorescence (PXRF) analysis was done at the Lawrence Berkeley National Laboratory (LBNL), for as this analysis clearly shows - the obsidian flake is not Malad, but is rather from a Mexican source. 
Table 3-1. Element Abundances and ratios for TOP-203 and Ucareo Chemical Group I ${ }^{1}$

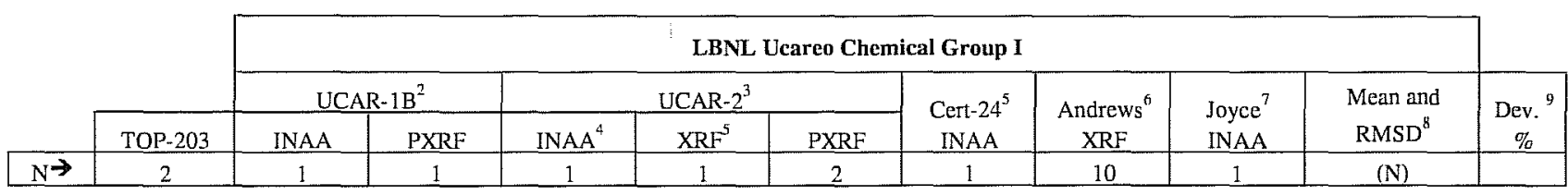

\begin{tabular}{|c|c|c|c|c|c|c|c|c|c|c|c|}
\hline \multicolumn{12}{|c|}{ Element abundances } \\
\hline $\mathrm{Fe}, \%$ & $0.757 \pm .015$ & $0.762 \pm .010$ & $0.767 \pm .015$ & $0.761 \pm .015$ & - & $0.754 \pm .015$ & $0.761 \pm .013$ & --.--..- & -----...- & $0.760 \pm .014(6)$ & -0.4 \\
\hline $\mathrm{Rb}$ & $150 \pm 3$ & $152 \pm 4$ & $152 \pm 3$ & $129 \pm 13$ & --------- & $154 \pm 3$ & $164 \pm 8$ & -------- & ------ & $153 \pm 3(4)$ & -2.0 \\
\hline$Y$ & $24.8 \pm .5$ & $-\ldots$ & $23.8 \pm .5$ & - ---.--- & & $24.9 \pm .5$ & - & & ----_- & $24.5 \pm .8(3)$ & +1.2 \\
\hline $\mathrm{Zr}$ & $120 \pm 2$ & ------- & $112 \pm 2$ & ------ & & $115 \pm 2$ & -------- & - & - & $114 \pm 2(3)$ & +5.3 \\
\hline $\mathrm{Nb}$ & $13.0 \pm .3$ & ----.-..- & $12.7 \pm .3$ & ------. & -----.--- & $13.2 \pm .3$ & - ------- & $-\ldots-\cdots-$ & --------- & $13.0 \pm .3(3)$ & +0.0 \\
\hline Th & $15.4 \pm .7$ & $15.2 \pm .2$ & $14.7 \pm .6$ & $15.4 \pm 0.2$ & --------- & $15.8 \pm 0.6$ & $14.8 \pm 0.2$ & -------- & ------- & $15.3 \pm 0.6(6)$ & +0.7 \\
\hline $\mathrm{Sr}$ & $14.8 \pm .8$ & | -----.-- & $13.0 \pm .8$ & - ---...-.. & -...---- & $13.0 \pm .8$ & | -----..- & -..-- & -..-..-- & $13.0 \pm .8(3)$ & +13.8 \\
\hline $\mathrm{Ba}$ & $172 \pm 5$ & $157 \pm 12$ & $138 \pm 5$ & $120 \pm 9$ & $144 \pm 9$ & $132 \pm 5$ & $128 \pm 8$ & $135 \pm 8$ & 115 & $134 \pm 5(3)$ & +28.4 \\
\hline
\end{tabular}

Average Deviation for 8 element abundances $=6.5 \%$

\begin{tabular}{|c|c|c|c|c|c|c|c|c|c|c|c|}
\hline \multicolumn{12}{|c|}{ Element abundance ratios from PXRF or XRF measurements } \\
\hline $\mathrm{Sr} / \mathrm{Zr}$ & $0.124 \pm .003$ & -...-.--- & $0.116 \pm .003$ & $---\cdots-\cdots$ & $0.10 \pm .02$ & $0.114 \pm .003$ & -..--.-- & $0.119 \pm .011$ & -------- & $0.115 \pm .003(3)$ & +7.8 \\
\hline $\mathrm{Rb} / \mathrm{Zr}$ & $1.258 \pm .009$ & ......-- & $1.363 \pm .009$ & 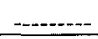 & $1.28 \pm .07$ & $1.344 \pm .009$ & (n-...-...- & $1.333 \pm .043$ & - & $1.350 \pm .013(3)$ & -6.8 \\
\hline
\end{tabular}

Average deviation for 2 element abundance ratios $=7.3 \%$

\begin{abstract}
'Abundances are expressed in parts-per-million except for those of $\mathrm{Fe}$, which are expressed in per cent (\%). Generally, errors are the larger of the counting errors or, for multiple samples, the Standard Deviations. If PXRF measurements have counting errors below $2 \%$, the latter is taken as the precision of measurement. If ratios of abundances are taken, however, between $\mathrm{Rb}, \mathrm{S} r$ and $\mathrm{Zr}$, some systematic uncertainties cancel out and the errors are taken as the counting errors. When LBNL INAA measurements have counting errors below $1 \%$, the latter is taken as the precision of measurement.

${ }^{2}$ One of two blades collected by Terence Stocker at Ucareo and given to Asaro and Stross via Robert Heizer.

${ }^{3}$ Source sample kindly provided by F. Nelson who had received it from Robert Cobean.

${ }^{4}$ Unpublished INAA data of F. Asaro, H. V. Michel and F. H. Stross.

${ }^{5}$ Andrews et al. 1989

${ }^{6}$ Ten (Cert-4, $-6,-7,-8,-12,-22,-23,-24,-28$, and Cert-31) of the 18 samples that Andrews et al. assigned to Ucareo which were measured by XRF. ${ }^{7}$ Joyce et al. 1995. Of the nine artifacts assigned to Ucareo by Joyce et al., we assigned RV013 and RV061 to our subgroup I, RV012, RV044, RV057, RV058 and RV060 to our Subgroup II.

${ }^{8}$ Mean value for the number of measurements shown in parentheses, i.e. the most precisely measured values. The listed error is the larger of the measurement error or the root-mean-square deviation.

${ }^{9}$ Dev. $=$ Deviation $=100 \times(($ TOP-203 abundance $/$ Mean value $)-1)$
\end{abstract}

\section{Methods and Results of PXRF Analysis}

The artifact from San Juan Capistrano was designated as TOP-203, analyzed as part of the Texas Obsidian Project, in which the authors have long been involved. After receipt at the LBNL, the specimen was analyzed by Giauque using the PXRF technique described in Giauque et al. (1993).

Of the elements measured, eight had the precision and reliability useful for source provenience determination. After a preliminary source attribution was made, the data were compared to 24 reference specimens from the potential source area, all of these having been published in Stross et al. (1983). This meant that data obtained through neutron activation analysis (INAA) and other x-ray fluorescence techniques (all done at LBNL) had also been applied to potential source area reference samples.

These reference samples had been assigned to a Mexican geologic source known as Ucareo, in the state of Michoacan (Figure 3-2), and could be subdivided into three groups, mainly characterized by their Ba contents as indicated in Tables 3-1 and 3-2. For Group I, the average $\mathrm{Ba}$ content for three samples is $134 \pm 5$, for Group II - Ba for 20 samples is $169 \pm 11$, and for Group III - Ba for two samples is $201 \pm 5$. The values after the \pm signs are standard deviations.

The trace element abundances for TOP-203 and reference samples for eight elements determined by the techniques indicated above, and $\mathrm{Sr} / \mathrm{Zr}$ as well as $\mathrm{Rb} /$ $\mathrm{Zr}$ evaluated by PXRF determinations are shown in Tables $3-1$ to $3-3$. The deviations of the element 
Table 3-2. Element abundances and ratios for TOP-203 and Ucareo Chemical Group II ${ }^{1}$

\begin{tabular}{|c|c|c|c|c|c|c|c|c|}
\hline & & \multicolumn{7}{|c|}{ LBNL Ucareo Chemical Group II } \\
\hline & \multirow{2}{*}{$\begin{array}{l}\text { TOP-203 } \\
\text { PXRF }\end{array}$} & \multirow{2}{*}{$\begin{array}{l}\text { LBNL }^{2} \\
\text { INAA }\end{array}$} & \multirow{2}{*}{$\begin{array}{l}\text { Joyce }^{3} \\
\text { INAA }\end{array}$} & \multicolumn{2}{|c|}{ UCAR-IA (LBNL) ${ }^{4}$} & \multirow{2}{*}{$\begin{array}{c}\text { LBNL }^{5} \\
\text { XRF }\end{array}$} & \multirow{2}{*}{$\begin{array}{c}\text { Mean and RMSD } \\
\text { of } N \text { values }\end{array}$} & \multirow{2}{*}{$\begin{array}{c}\text { Dev. }^{7} \\
\% \\
\end{array}$} \\
\hline & & & & INAA & PXRF & & & \\
\hline $\mathrm{N} \rightarrow$ & 1 & 5 & 5 & 1 & 1 & 8 & (N) & \\
\hline
\end{tabular}

\begin{tabular}{|c|c|c|c|c|c|c|c|c|}
\hline \multicolumn{9}{|c|}{ Elcment abundances } \\
\hline $\mathrm{Fe}, \%$ & $0.757 \pm .015$ & $0.788 \pm .018$ & -------- & $0.760 \pm .010$ & $0.773 \pm .015$ & 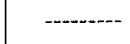 & $0.782 \pm .018(7)$ & -3.2 \\
\hline $\mathrm{Rb}$ & $150 \pm 3$ & $157 \pm 8$ & -..---- & $153 \pm 4$ & $150 \pm 3$ & -.----- & $152 \pm 4(2)$ & -1.3 \\
\hline $\mathrm{Y}$ & $24.8 \pm .5$ & ----..- & -.........- & .........- & $24.0 \pm .5$ & 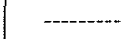 & $24.0 \pm .5(1)$ & +3.3 \\
\hline $\mathrm{Zr}$ & $120 \pm 2$ & -.--.... & -........- & …--- & $118 \pm 2$ & - & $118 \pm 2(1)$ & +1.7 \\
\hline $\mathrm{Nb}$ & $13.0 \pm .3$ & - & ----- & - ---.-- & $12.9 \pm .3$ & -...-.-- & $12.9 \pm .3(1)$ & +0.8 \\
\hline $\mathrm{Th}$ & $15.4 \pm .7$ & $14.8 \pm 0.2$ & -......- & $14.9 \pm 0.2$ & $15.5 \pm .6$ & -........ & $14.8 \pm 0.2(6)$ & +4.1 \\
\hline $\mathrm{Sr}$ & $14.8 \pm .8$ & .....-- & - ---...... & (-.......... & $14.3 \pm .8$ & - & $14.3 \pm .8(1)$ & +3.5 \\
\hline $\mathrm{Ba}$ & $172 \pm 5$ & $163 \pm 10$ & $166 \pm 9$ & $166 \pm 12$ & $162 \pm 5$ & $177 \pm 11$ & $169 \pm 11(20)$ & +1.8 \\
\hline
\end{tabular}

Average Deviation for 8 element abundances $=2.5 \%$

\begin{tabular}{|c|c|c|c|c|c|c|c|c|}
\hline \multicolumn{9}{|c|}{ Element abundance ratios from PXRF or XRF measurements } \\
\hline $\mathrm{Sr} / \mathrm{ZT}$ & $0.124 \pm .003$ & -.......- & -.------ & -------- & $0.121 \pm .003$ & $0.137 \pm .032$ & $0.121 \pm .003(1)$ & +2.5 \\
\hline $\mathrm{Rb} / \mathrm{Zr}$ & $1.258 \pm .009$ & -.-....... & -.......... & .........- & $1.269 \pm .009$ & $1.231 \pm .041$ & $1.269 \pm .009(1)$ & -0.9 \\
\hline
\end{tabular}

\footnotetext{
'Abundances are expressed in parts-per-million except for those of $\mathrm{Fe}$, which are expressed in per cent (\%). Generally, errors are the larger of the counting errors or, for multiple samples, the Standard Deviations. If PXRF measurements have counting errors below $2 \%$, the latter is taken as the precision of measurement. If ratios of abundances are taken, however, between $\mathrm{Rb}, \mathrm{Sr}$ and $\mathrm{Zr}$, some systematic uncertainties cancel out and the errors are taken as the counting errors. When LBNL INAA measurements have counting errors below $1 \%$, the latter is taken as the precision of measurement.

${ }^{2}$ Three artifacts (Cert-3, $-9,-25$ ) from Andrews et al. 1989, one artifact (Tikal-4) from Moholy-Nagy et al. 1984 and one artifact (786-T) received from N. Hammond and referred to in Stross et al. 1978.

${ }^{3}$ Joyce et al. 1995. Of the nine artifacts assigned to Ucareo by Joyce et al., we assigned RV013 and RV061 to our subgroup I and RV012, RV044, RV057, RV058 and RV060 to our Subgroup II.

${ }^{4}$ One of two blades collected by Terence Stocker from Ucareo

${ }^{5}$ Six artifacts (Cert-3, $-5,-9,-11,-25$ and Cert-34) from Andrews et al. 1989. One (Juan-17) from Guderjan et al. 1989 and one (Tikal-4) from MoholyNagy et al. 1984.

${ }^{6} \mathrm{RMSD}$ is the larger of the average measurement error or the root-mean-square deviation of the N samples

${ }^{7}$ Dev. $=$ Deviation $=100 \times(($ TOP-203 abundance $/$ Mean $)-1)$
}

abundances of TOP-203 from the averages of those of the corresponding reference samples are shown in the last columns of these three tables. Similarly, the deviations of the $\mathrm{Sr} / \mathrm{Zr}$ and $\mathrm{Rb} / \mathrm{Zr}$ ratios are shown in the tables below the values for the abundances.

The average deviations for the element abundances and ratios in TOP-203 from the reference samples for Group I are 6.5\% and 7.3\% respectively. For Group $\Pi$, the corresponding values are $2.5 \%$ and $1.7 \%$, and for Group III, $7.9 \%$ and $13.7 \%$. On the basis of these results, TOP-203 was assigned a provenience of Group II of the Ucareo source.

\section{The Ucareo, Michoacan Source}

The initial geochemical characterization of the Ucareo source was published by Hester et al. (1973), along with its nearby "twin" source of Zinapecuaro. These had been used at Tula as the principal non-green (Sierra de las Navajas) obsidian, although the well-known source of Otumba (with its black obsidian) is much closer to the site.

Subsequently, much new and important research at the Michoacan obsidian sources has been done by Dan M. Healan of Tulane University (cf. Healan 1993 and especially Healan 1997). Healan's 1997 study measured 17 source samples coming specifically from Ucareo, and also included analyses of sources from nearby sources such as Zinapecuaro and Cruz Negra. Healan's results indicated that while Ucareo was a distinctive source, there was internal variability within the samples analyzed. Healan very kindly sent Asaro (personal communication, 1998) a detailed listing of the trace elements abundances measured for each of the source samples, using INAA (University of 
Table 3-3. Element abundances and ratios for TOP-203 and Ucareo Chemical Group III ${ }^{1}$

\begin{tabular}{|c|c|c|c|c|c|}
\cline { 2 - 6 } \multicolumn{1}{c|}{} & \multicolumn{4}{c|}{ LBNL Ucareo Chemical Group III } \\
\cline { 2 - 6 } \multicolumn{1}{c|}{$\begin{array}{c}\text { TOP-203 } \\
\text { PXRF }\end{array}$} & $\begin{array}{c}\text { LBNL }^{2} \\
\text { INAA }\end{array}$ & $\begin{array}{c}\text { LBNL }^{3} \\
\text { XRF }\end{array}$ & Mean Value $^{4}$ & $\begin{array}{c}\text { Dev }^{5} \\
\%\end{array}$ \\
\hline
\end{tabular}

\begin{tabular}{|c|c|c|c|c|c|}
\hline \multicolumn{6}{|c|}{ Element abundances } \\
\hline $\mathrm{Fe}, \%$ & $0.757 \pm .015$ & $0.788 \pm .018$ & -..-- & $0.788 \pm .018(1)$ & -3.9 \\
\hline $\mathrm{Rb}$ & $150 \pm 3$ & $164 \pm 8$ & ----..-- & $164 \pm 8(1)$ & -8.5 \\
\hline $\mathrm{Y}$ & $24.8 \pm .5$ & - & - & (n- & \\
\hline $\mathrm{Zr}$ & $120 \pm 2$ & 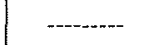 & ---- & ----o-- & \\
\hline $\mathrm{Nb}$ & $13.0 \pm .3$ & - & & ---.--..- & \\
\hline $\mathrm{Th}$ & $15.4 \pm .7$ & $14.7 \pm 0.2$ & -.....-. & $14.7 \pm 0.2(1)$ & +4.8 \\
\hline $\mathrm{Sr}$ & $14.8 \pm .8$ & - & |--...-..- & | ------ & \\
\hline $\mathrm{Ba}$ & $172 \pm 5$ & $197 \pm 8$ & $201 \pm 5$ & $201 \pm 5(2)$ & -14.4 \\
\hline
\end{tabular}

Average Deviation for 4 element abundances $=7.9 \%$

\begin{tabular}{|c|c|c|c|c|c|}
\hline \multicolumn{6}{|c|}{ Element abundance ratios from PXRF or XRF measurements } \\
\hline $\mathrm{Sr} / \mathrm{Zr}$ & $0.124 \pm .003$ & -.-----. & $0.139 \pm .018$ & $0.139 \pm .018(2)$ & -10.8 \\
\hline $\mathrm{Rb} / \mathrm{Zr}$ & $1.258 \pm .009$ & $\ldots$ & $1.079 \pm .039$ & $1.079 \pm .039(2)$ & +16.6 \\
\hline
\end{tabular}

Average deviation for 2 element abundance ratios $=13.7 \%$

\begin{abstract}
${ }^{1}$ Abundances are expressed in parts-per-million except for those of Fe, which are expressed in per cent (\%). Generally, errors are the larger of the counting errors or, for multiple samples, the Standard Deviations. If PXRF measurements have counting errors below $2 \%$, the latter is taken as the precision of measurement. If ratios of abundances are taken, however, between $\mathrm{Rb}$, $\mathrm{Sr}$ and $\mathrm{Zr}$, some systematic uncertainties cancel out and the errors are taken as the counting errors. When LBNL INAA measurements have counting errors below $1 \%$, the latter is taken as the precision of measurement.

${ }^{2}$ Andrews et al. 1989. Sample Cerl-14

${ }^{3}$ Cert-14 and Cert-13 from Andrews et al. 1989

${ }^{4}$ Mean value for the number of measurements shown in parentheses, i.e. the most precisely measured values. The listed error is the measurement error for one sample and the larger of the measurement error or the root-mean-square deviation for multiple samples.

${ }^{5}$ Dev. $=$ Deviation $=100 \times(($ TOP-203 abundance $/$ Mean value $)-1)$
\end{abstract}

Missouri Research Reactor) and by XRF (by Stephen Nelson). With these data in hand, Asaro and Stross found excellent agreement between chemical Group II at Ucareo and the upper part of the Ucareo source deposit. All of this leaves little doubt that TOP203 is originally derived from the obsidian source at Ucareo, Michoacan.

\section{Implications}

Now that TOP-203 has been linked to the Ucareo, Michoacan obsidian source, we have to examine how it may have reached San Juan Capistrano, presumably in the eighteenth century (based on artifact associations from the UTSA excavations). Clearly, obsidian was worked in central Mexico (and beyond) well into the Spanish Colonial period. Dating of this technology is seen in the association of Colonial ceramics in the Valley of Mexico, and efforts have been made (notably Michels 1971) to refine the dating of obsidian-working by using obsidian hydration analysis. Michels (1971:267) suggests that obsidian was used in "Early and Late Colonial periods" with what is "noticeably... a progressive reduction in number of artifacts as we move from early to late Colonial times."

Based on Campbell and Campbell (1983), there were no known Indian groups at San Juan Capistrano that came from deep in Mexico. There were, of course, displaced peoples, such as the Borrado and Venado, who originated in Nuevo Leon and Tamaulipas, and might have acquired some bits of obsidian from other Mexican groups, taking some of it with them to the mission.

Tlaxcalan (or Tlaxcaltecan) Indians, Spanish allies and agriculturalists from southern Mexico, east of Mexico City, were settled in Saltillo in 1591 (Cuella Valdes 1979). During the establishment of missions in Texas during 
the eighteenth century, mention is often made of bringing Tlaxcalan families into the missions to serve as a "positive influence" on the hunters and gatherers who resided there (Weddle 1968). It is likely that the Tlaxcalans, like the Mission Indians, continued some form of stone-tool making and use (Hester 1989), but we have no clear evidence of this. And, while they came from an area which had access to obsidian sources, and where they would have certainly worked and used obsidian, there is no link between them and the Ucareo regions.

Perhaps the presence of the Ucareo specimen (TOP203) was simply introduced via the importation of goods from Saltillo, some of which derived from other parts of Mexico. Whatever the explanation, the presence of this one small artifact is further evidence -which we sometimes simplify or ignore- of the dynamics of the Spanish Colonial missions. 


\section{References Cited}

Andrews, A. P., F. Asaro, H. V. Michel, F. H. Stross, and P. C. Rivero

1989 The Obsidian Trade at Isla Cerritos, Yucatan, Mexico. Journal of Field Archaeology 16:355-363.

Campbell, T. N., and T. J. Campbell

1985 Indian Groups Associated with the Spanish Missions of the San Antonio Missions National Historical Park. Special Report 16. Center for Archaeological Research, The University of Texas at San Antonio.

Cuellar Valdes, P. M.

1979 Historia del Estado de Coahuila. Biblioteca de la Universidad Autonoma de Coahuila, Volumen 1. Saltillo.

Giauque, R., F. Asaro, F. H. Stross, and T. R. Hester

1993 High Precision Non-Destructive X-Ray Fluorescence Method Applicable to Establishing the Provenance of Obsidian Artifacts. X-Ray Spectrometry 22:44-53.

Guderjan, T. H., J. F. Garber, H. A. Smith, F. Stross, H. V. Michel, and F. Asaro

1989 Maya Maritime Trade and Sources of Obsidian at San Juan, Ambergris Cay, Belize. Journal of Field Archaeology 16:363-369.

Healan, D. M.

1993 Local Versus Non-Local Obsidian Exchange at Tula and its Implications for Post-Formative Mesoamerica. World Archaeology 24(3):449-466.

1997 Pre-Hispanic Quarrying in the Ucareo-Zinapecuaro Obsidian Source Area. Ancient Mesoamerica 8(1):77-100.

Hester, T. R., R. N. Jack, and A. Benfer

1973 Trace Element Analyses of Obsidian from Michoacan, Mexico: Preliminary Results. Contributions of the University of California Archaeological Research Facility 18:167-176.

Joyce, A. A., J. M. Elam, M. D. Glascock, H. Neff, and M. Winter

1995 Exchange Implications of Obsidian Source Analysis from the Lower Rio Verde Valley, Oaxaca, Mexico. Latin American Antiquity 6(1):3-15.

Michels, J. W.

1971 The Colonial Obsidian Industry of the Valley of Mexico. In Science and Archaeology, R. H. Brill, ed., pp. 251-271. Cambridge, MA.

Mohology-Nagy, H., F. Asaro, and F. Stross

1984 Tikal Obsidian: Sources and Typology. American Antiquity 49(1):104-117.

Stross, F. H., H. R. Bowman, H. V. Michel, F. Asaro, and N. Hammond

1978 Mayan Obsidian Source Correlation for Southern Belize Artifacts. Archaeommetry 20(1):89-93.

Stross, F. H., P. Sheets, F. Asaro and H. Michel

1983 Precise Characterization of Guatemalan Obsidian Sources and Source Determination of Artifacts from Quirigua. American Antiquity 48:323-346.

Weddle, R. S.

1968 San Juan Bautista. Gateway to Spanish Texas. University of Texas Press, Austin. 



\section{Appendix IV \\ Isolated Burial Analysis}




\section{Isolated Burial Analysis}

\author{
Jeffrey R. Francis
}

\section{Introduction}

In 1996, the Center for Archaeological Research (CAR) at The University of Texas at San Antonio (UTSA) completed preliminary archaeological investigations south of Mission San Juan Capistrano. The work was conducted in an area specified to be impacted by a proposed 800 foot drainage channel. The channel was designed to direct rain water away from the southern portion of the mission compound. CAR excavated 43 shovel tests along the proposed route of the drainage channel (Figure 4-1). This monitoring project was conducted for the National Park Service under Antiquities Permit 1748 and a final report was published (Gross 1998). Although, during the 1996 investigation it was reported that no intact Colonial-period deposits were identified, it was recommended that an archaeologist be present to monitor the actual excavation of the channel when the project was undertaken. Therefore, in 1999, when the drainage channel project began, a staff archaeologist from CAR was present at the site.

During these excavations bone fragments were noticed in a portion of the trench. Excavations were immediately halted and the fragments were carefully collected. These fragments were taken to the laboratory at CAR, UTSA for proper identification. Upon inspection it was determined that the bones were of human origin. A brief analysis was then conducted at CAR and the remains were returned to the National Park Service (NPS). With the approval of the Texas Historical Commission (THC) the human remains were reinterred. The channel which was being excavated was then rerouted to avoid any further disturbance to the immediate area.

\section{Osteological Analysis}

This isolated single burial appears to represent a young adult female, 25-49 years of age. The recovered remains were represented by post-cranial elements only (Table 4-1). These elements consisted of a proximal
$2 / 3$ left femur with $<50 \%$ articular surface, a proximal $1 / 3$ left tibia, a distal $1 / 3$ right tibia with $<50 \%$ articular surface, a left fibula (diaphysis only), left tarsals consisting of a complete talus and fragments of the navicular, cuboid and lateral cuneiform, left second, third fourth and fifth metatarsals, left fourth and fifth metacarpals, 34 ilium fragments (side indeterminate), 9 unidentifiable human long bone fragments, 24 grams of unidentifiable human bone fragment, and five bovid bones. All elements were poorly preserved with much of the cortical surface badly pitted due to depositional taphonomic changes.

Based on the overall size of the long bones as well as the dimensions of the talus (Steele 1976) and the midshaft circumference of the femur (Black 1978) it was determined that the remains were those of a female

Ancestry was based on the morphology of the proximal left femur which was moderately platymeric and was determined to be Native American in origin.

Age was based on the fused epiphysis of the proximal left femur and fragment of iliac crest. There were no visible epiphyseal lines and there appeared to be no degenerative changes.

Stature was based on the estimated maximum length of left femur using the formula for sections 1 and 2 derived from Steele (1988). The estimated maximum length of the left femur was $41.94 \mathrm{~cm} \pm .86 \mathrm{~cm}$. In comparison with other burials recovered from Mission San Juan Capistrano the estimated length of this femur is within $0.49 \mathrm{~cm}$ of the mean for females recovered from Room 26 at San Juan (Francis 1999). This difference suggests that there is no significant difference between this burial and the population females at Mission San Juan during the Spanish colonial period. The estimated living stature of this individual is : $158 \pm 3 \mathrm{~cm}$ (Genovés 1967).

There appeared to be no pathology present. 


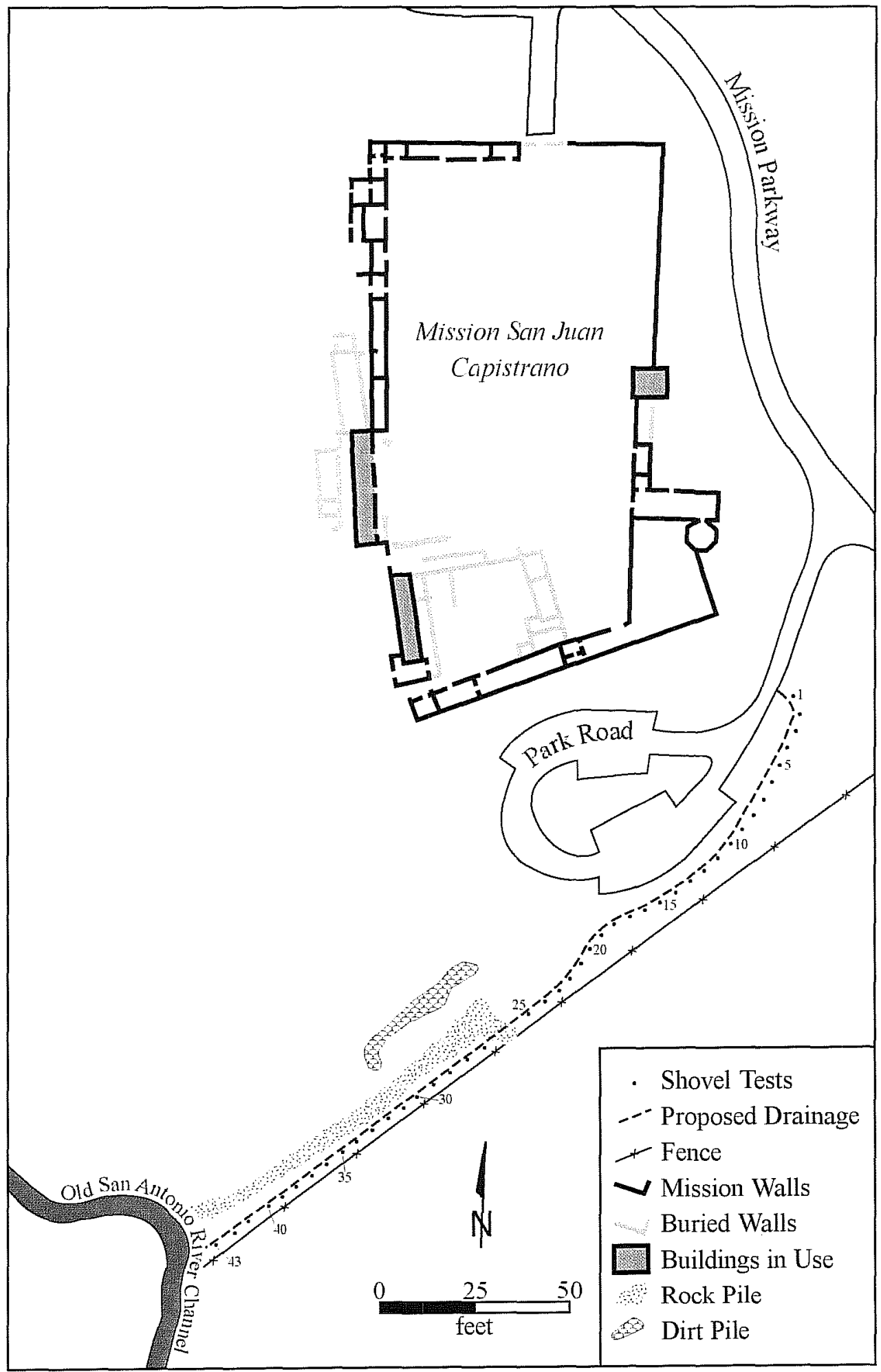

Figure 4-1. Route of proposed drainage channel and location of previously excavated shovel tests. (From Gross 1998) 
Table 4-1. Measurements of bones

\begin{tabular}{|c|c|c|}
\hline \multirow[t]{6}{*}{ Left Femur: } & Sub-trochanteric anterior-posterior diameter: & $23 \mathrm{~mm}$ \\
\hline & Sub-trochanteric medial-lateral diameter: & $32 \mathrm{~mm}$ \\
\hline & Anterior-posterior diameter@ midshaft: & $27 \mathrm{~mm}$ \\
\hline & Medial-lateral diameter@midshaft: & $24 \mathrm{~mm}$ \\
\hline & Circumference@midshaft: & $79 \mathrm{~mm}$ \\
\hline & Total Length: & $289 \mathrm{~mm}$ \\
\hline \multirow[t]{3}{*}{ Left Tibia: } & Anterior-posterior diameter@ nutrient foramen: & $31 \mathrm{~mm}$ \\
\hline & Medial-lateral diameter@nutrient foramen: & $21 \mathrm{~mm}$ \\
\hline & Total Length: & $155 \mathrm{~mm}$ \\
\hline Right Tibia: & Total Length: & $116 \mathrm{~mm}$ \\
\hline Left Fibula: & Total Length: & $249 \mathrm{~mm}$ \\
\hline \multirow[t]{5}{*}{ Left Talus: } & Maximum length: & $50 \mathrm{~mm}$ \\
\hline & Maximum width: & $35 \mathrm{~mm}$ \\
\hline & Body height: & $29 \mathrm{~mm}$ \\
\hline & Trochlear width: & $29 \mathrm{~mm}$ \\
\hline & Trochlear length: & $31 \mathrm{~mm}$ \\
\hline \multirow[t]{7}{*}{ Left Second Metatarsal: } & Anterior-posterior diameter@midshaft: & $0.9 \mathrm{~mm}$ \\
\hline & Medial-lateral diameter@midshaft: & $0.8 \mathrm{~mm}$ \\
\hline & Proximal breadth: & $15 \mathrm{~mm}$ \\
\hline & Proximal height: & $20 \mathrm{~mm}$ \\
\hline & Distal breadth: & $12 \mathrm{~mm}$ \\
\hline & Distal height: & Incomplete \\
\hline & Length: & $75 \mathrm{~mm}$ \\
\hline
\end{tabular}



